Pamiętnik Literacki 2013, 1, s. 135-164

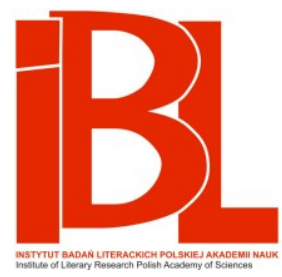

Negatywy pozytywów, czyli rzecz o fotografiach pisarzy

Grzegorz Olszański 


\section{NEGATYWY POZYTYWÓW, CZYLI RZECZ O FOTOGRAFIACH PISARZY}

\section{Lektura: rytual zatraty}

W jednym ze swych najbardziej znanych, ale też najbardziej kontrowersyjnych tekstów Roland Barthes przekonywał:

pisanie niszczy wszelki głos, wszelkie źródło i wszelki początek. Pisanie to sfera neutralności, złożoności, nieprzejrzystości, w której znika nasz podmiot, negatyw, na którym niknie wszelka tożsamość odnajdująca siebie w piszącym ciele ${ }^{1}$.

Radykalizm tego manifestu - jak większość terrorystycznych zamachów u swej genezy miał, oczywiście, jak najbardziej szlachetne intencje. Chodziło wszak nie tylko o przyjemność płynącą ze swoistej ,,jazdy bez trzymanki" ${ }^{2}$, ale przede wszystkim o likwidację dotychczasowego nadzorcy sensu, kres paternalistycznej władzy, wybicie się czytelnika na lekturową niepodległość.

Jak każda rewolucja, tak i ta nie mogła obejść się bez ofiar; „,narodziny czytelnika trzeba przypłacić śmiercią Autora" ${ }^{3}$ - przekonywał w finalnym zdaniu swej odezwy Barthes, nie pozostawiając najmniejszej wątpliwości, kto w jakiej roli jest tutaj obsadzony. Pismo stawało się więc medium tyleż kreacji, co zatraty, a proces, który początek miał w jego naturze, koniec znajdował w projektowanym przez autora Światta obrazu fenomenie odbioru. Fenomenie, z jednej strony, negującym antyczny topos pisania jako drogi do nieśmiertelności oraz romantyczny mit literatury jako przede wszystkim formy wyrażania ,ja”, z drugiej zaś - czerpiącym $\mathrm{z}$ równie mocno zakorzenionego w kulturze obrazu grobu stanowiącego też kolebkę. Lektura jako akt twórczy stawała się tu bowiem zarazem swoistą ceremonią żałobną, o czym nieco bardziej obrazowo i z widocznym przekąsem blisko 20 lat wcześniej pisał inny słynny francuski filozof:

1 R. B a r th e s, Śmierć autora. „Teksty Drugie” 1999, nr 1/2, s. 247 (przeł. M. P. M a r k o ws k i). Gwoli ścisłości wypada przypomnieć, że R. B a r th e s - o czym najlepiej świadczą początkowe strony książki Sade, Fourier, Loyola (Przeł. R. L i s. Warszawa 1996) - dosyć szybko zaczął się wycofywać z przytoczonych stwierdzeń i zdecydowanie złagodził swe stanowisko.

2 Odwołuję się tu, może nieco niezdarnie, do metaforyki samego B a r th e s'a, który w pewnym momencie konstatował: „Przydać Autorowi tekst to zaopatrzyć ów tekst w hamulec bezpieczeństwa [...]" (Śmierć autora, s. 250).

Ibidem, s. 251. 
Krytykowi źle się powodzi, żona nie ceni go tak, jak by należało, synowie są niewdzięczni, a koniec miesiąca trudny. Lecz zawsze można wejść do biblioteki, wziąć z półki książkę i otworzyć. Ulatnia się z niej lekka woń piwnicy i zaczynają się osobliwe zabiegi, które on postanowił nazywać czytaniem. Pod pewnym względem jest to rodzaj opętania: oddaje się zmarłym swoje ciało, aby mogli ożyć. Pod innym - to kontakt z zaświatem ${ }^{4}$.

Zbliżona metaforyka nie powinna nas, oczywiście, mylić. Projekt lektury, który w swym tekście proklamował Barthes, był w końcu zdecydowanie bardziej radykalny, zważywszy, że istotę tego projektu stanowiło raczej zapomnienie niż pamięć. W tym kontekście trudno się dziwić, iż propozycje autora $S / Z$ zdecydowanie entuzjastyczniej przyjęli badacze literatury niż jej twórcy. Patrząc z dzisiejszej perspektywy, w przypadku jednych i drugich wydaje się to zresztą gestem tyleż anarchistycznym, co anachronicznym. Rzecz bowiem w tym - co świetnie pokazał Ryszard $\mathrm{Nycz}^{5}-\dot{z} e$ jednym z najistotniejszych rysów modernistycznego przełomu była przecież próba radykalnego zerwania więzi między autorem a jego tekstowym reprezentantem, o czym skrupulatnie zaświadczają zarówno utwory literackie, jak i podręczniki poetyki. Z drugiej strony (to z kolei lekcja płynąca z socjologii literatury), o ile pojawiające się wówczas postulaty „depersonalizacji” i „odejścia autora” przekładały się na znaczną część praktyki literackiej, to zarazem, jak łatwo się domyślić, nie wpływały one jednak na praktykę wydawniczą. Innymi słowy, nawet jeśli niektórzy deklarowali, iż „Rozwój artysty to bezustanne poświęcanie samego siebie i stała zagłada swojej osobowości" 6 , pisanie zaś tożsame jest $\mathrm{z}$ „wkroczeniem we własną śmierć" podkreślać, kto $\mathrm{w}$ ową śmierć właśnie wkroczył i czyja zagłada się dokonała. A nawet jeśli mieli (przypominam tu casus Edwarda Stachury, od czasów publikacji Całej jaskrawości podejmującego próby wydawania swych tekstów bez sygnowania ich nazwiskiem autora ${ }^{8}$ ), to zazwyczaj skutecznie przeciwstawiali się temu ci, którzy ich książki zwykli publikować. Na delikatne i częstokroć skomplikowane relacje łączące autora $\mathrm{z}$ kreowanymi postaciami, a świat przedstawiony $\mathrm{z}$ realnym, nakładały się w tym miejscu zdecydowanie mniej subtelne, choć nierzadko równie złożone, relacje ekonomiczno-prawne, a w ich kontekście twórca stawał się wytwórcą, jego nazwisko - znakiem towarowym, tekst zaś produktem. Czytelnym (i zazwyczaj nie podlegającym negocjacji ${ }^{9}$ ) znakiem relacji przynależności (acz już własności niekoniecznie) są pojawiające się na okładce imię i nazwisko autora. Ponieważ stawką w grze wydaje się nie tylko poczytność, ale i rozpo-

4 J.-P. S a r $\mathrm{tr}$ e, Czym jest literatura? Wybór szkiców krytycznoliterackich. Wybór A. T a t a rki e w i c z. Przeł. J. La le wi c z. Wstęp T. M. J a r o s z e w sk i. Warszawa 1968, s. 178-179.

5 R. N y c z, Osoba w nowoczesnej literaturze: ślady obecności. W: Literatura jako trop rzeczywistości. Poetyka epifanii w nowoczesnej literaturze polskiej. Kraków 2001. Interesujący mnie fragment, dotyczący m.in. koncepcji Barthes'a, znajduje się na s. 54-58.

6 Th. S. E 1 i o t, Tradycja i talent indywidualny. W: Kto to jest klasyk i inne eseje. Kraków 1998, s. 28 (przeł. H. Prę c zk ow s k a).

7 B a r th e s, Śmierć autora, s. 247.

8 Dokładnie opisuje tę sprawę biograf autora Siekierezady. Zob. M. B u c h o w s k i, Edward Stachura. Biografia i legenda. Opole 1992, s. 162-163.

9 Chodzi mi tu o powszechny uzus, który - rzecz jasna - jak każdy, bywa czasem naruszany (kwestia plagiatów, tworzenia pod pseudonimem, coraz bardziej jawne funkcjonowanie instytucji ghost writerów etc.). Zważywszy na proporcje i częstotliwość tego rodzaju praktyk, można je chyba traktować jako zjawisko sytuujące się na marginesie życia literackiego. 
znawalność, ta autorska sygnatura często zyskuje dodatkowe wsparcie w postaci notki biograficznej (jej przemiany stanowią temat na osobny szkic) oraz zdjęcia. To właśnie ono, jego poetyka, funkcje i znaczenia będą mnie tutaj interesować.

\section{Robić, oglądać...}

Fotografia - po raz kolejny przychodzi mi tu odwołać się do słów Barthes’a - może być ,przedmiotem trzech praktyk (lub trzech emocji czy trzech intencji): robić, czemuś podlegać, oglądać" ${ }^{10}$. Te trzy praktyki - oczywiście na różne sposoby - występują też w literaturze. Pisarze robią zdjęcia, a potem próbują wykorzystać to doświadczenie w swoich książkach, aparat fotograficzny coraz częściej pełni zaś funkcję notatnika, stając się jeśli nie elementarnym, to przynajmniej zalecanym narzędziem pisarskiego fachu ${ }^{11}$. W ramach oczywistych, ale też zróżnicowanych przykładów dość wymienić:

- casus książek Winfrieda Georga Sebalda, gdzie autorskie (bądź wykonywane według autorskich pomysłów) zdjęcia odgrywają niezwykle istotną rolę;

- fotoeseje (gatunek, który - jak sama nazwa wskazuje - bez fotografii nie mógłby istnieć ${ }^{12}$ ) w rodzaju The Colonial Harem Maleka Allouli czy Another Way of Telling Jeana Mohra i Johna Bergera;

- głośny tom Tadeusza Różewicza Matka odchodzi, gdzie wiersze, fragmenty prozy i autentycznego dziennika funkcjonują niemal na równych prawach, jak zamieszczone tam zdjęcia;

- wreszcie - cały szereg utworów na różne sposoby tematyzujących sam akt wykonywania fotografii:

Nie ruszaj się; tak, brawo;

tylko poczekam, aż

przejdą ci ludzie i sprawy

[.......... . . $]$

${ }^{10}$ R. B a r the s, Światto obrazu. Uwagi o fotografii. Przeł. J. Tr z n a d e 1. Warszawa 1995, s. 17.

${ }^{11}$ Świadczy o tym fakt, że na rynku poradników pisarskich istnieje osobny segment dotyczący zastosowania aparatu fotograficznego w profesji pisarza. Zob. np. M. H a v e 1 i n, Photography for Writers: Using Photography to Increase Your Writing Income. New York 1998. - D . D a v e n p o r t, Successful Photography for Writers. London 2002. Nawiasem mówiąc, po narodzinach nowego medium, opierając się na koncepcji fotografii jako nowego (a według niektórych: wręcz najdoskonalszego) języka, wielokrotnie próbowano szukać analogii między profesją pisarza i fotografa. Zob. J. S z a r k o w s k i, Mirrors and Images. American Photography since 1960. New York 1978, s. 14. Cyt. za: B. S ti e g l e r, Obrazy fotografii. Album metafor fotograficznych. Przeł. J. C z u d e c. Kraków 2009, s. 168: „Podczas pierwszego stulecia swego istnienia zawodowy fotograf odgrywał podobną rolę jak niegdyś pisarz, zapisujący wieści i dokumenty potrzebne niepiśmiennemu mieszczaninowi czy często niewykształconemu władcy". W tym kontekście warto, być może, przypomnieć, że jednym z określeń, którym posługiwał się W. H. F. Talbot w odniesieniu do swego wynalazku, jest ,words of light”, a tacy artyści, jak Man Ray czy Walker Evans zestawiali maszynę do pisania $\mathrm{z}$ aparatem.

${ }^{12}$ Gatunek ten (inne określenie to „visual essay”) - przynajmniej w odniesieniu do rodzimej nauki - budzi chyba większe zainteresowanie teoretyków fotografii niż genologów. Zob. na ten temat K. O l e chni cki, Teoria i praktyka eseju fotograficznego. W: Antropologia obrazu. Fotografia jako metoda, przedmiot i medium nauk społecznych. Warszawa 2003. - S. S i k o r a, Autobiografia stworzona z fotografii. Metafora $w$ fotografii. W: Fotografia. Między dokumentem a symbolem. Izabelin 2004. 
[...] o tak, stój

właśnie tak; tylko nastawię

ostrość, żeby na jawie

uchwycić twój sen $[\ldots]^{13}$

przy zdjęciu głodu ze stołu

trzeba dobrze uchwycić garnek

ostrość noża i miękkość chleba

wtedy wszystko zdejmie się ze stołu ${ }^{14}$

Pisarze, oczywiście, nie tylko robią zdjęcia samodzielnie (niektórzy nawet z czasem zaczynają przedkładać aparat nad maszynę do pisania ${ }^{15}$ ), ale również przeglądają albumy, studiują prace słynnych fotografików (niekiedy, np. jak Henry Miller w odniesieniu do George'a Brassaïa, czynią ich bohaterami swoich książek), oglądają wystawy. Robią więc dokładnie to, co większość miłośników tego medium. I znów starają się wyzyskać to doświadczenie na różne sposoby. W efekcie czytelnik choćby po 200 przeszło stronicach książki Andrzeja Stasiuka Jadac do Babadag może natknąc się na taki oto fragment, w którym autor odkrywa przed nim niezwykłą genezę tej i innych swoich opowieści:

Niewykluczone, że wszystko, co napisałem do tej pory, zaczęło się od tej fotografii. Jest rok 1921 w niewielkim węgierskim miasteczku Abony, siedem kilometrów na zachód od Szolnok. W poprzek ulicy idzie niewidomy skrzypek i gra. Prowadzi go kilkunastoletni bosy chłopak w kaszkiecie. [...]

Od czterech lat prześladuje mnie to zdjęcie. Dokąd się nie wybiorę, szukam jego trójwymiarowych i barwnych wersji i często wydaje mi się, że znajduję. [...] Przestrzeń tego zdjęcia hipnotyzuje mnie i wszystkie moje podróże służą tylko temu, by w końcu odnaleźć ukryte przejście do jej wnętrza ${ }^{16}$.

Motorem narracji może więc być słynne zdjęcie słynnego fotografika (w tym przypadku André Kertésza), lecz także zupełnie anonimowe fotografie znalezione w antykwariatach i na pchlich targach. To z kolei casus ostatniej książki Jacka Dehnela (Fotoplastikon), gdzie autor, wykorzystując tradycje ekfrazy, próbuje dopisać własne historie do starych, przedwojennych zdjęć. W telegraficznym skrócie - ale też każde ze wspomnianych zagadnień ma osobną i, przede wszystkim, całkiem pokaźną bibliografię $e^{17}$ - można powiedzieć, że fotografia służy pisarzom równie

13 S. B a r a ń c z a k, Fotografia. W: Widokówka z tego świata i inne rymy z lat 1986-1988. Paryż 1988, s. 42.

${ }^{14}$ T. K a r p o w i c z, Poradnik fotografa. W: Wimie znaczenia. Wrocław 1962, s. 13-14.

15 Dobrym przykładem takiej zamiany profesji mógłby być Wojciech Wilczyk, poeta kojarzony niegdyś z formacją „,bruLionu”, który dziś bardziej znany jest jako fotografik, a liczba opublikowanych przez niego albumów fotograficznych przekracza liczbę sygnowanych jego nazwiskiem tomików poetyckich.

16 A. S t a s i u k, Jadac do Babadag. Wołowiec 2004, s. 209-210.

17 Aby nie być gołosłownym, przywołam kilka przykładowych prac, których autorzy - często z bardzo różnych perspektyw - analizują związki fotografii i literatury: B. Wi to s z, Opis a fotografia. „Zeszyty Naukowe Uniwersytetu Śląskiego” 1998, nr 25. - A. Ł e b k o w s k a, Fotografia jako empatyczna mediacja. W zb.: Intersemiotyczność. Literatura wobec innych sztuk (i odwrotnie). Red. S. Balbus, A. Hejmej, J. Niedźwiedź. Kraków 2004. - R. K. P r z y b y 1 s k i, Jak fotografia zahacza o rzeczywistość? A jak literatura wiąze się z fotografią. W zb.: jw. - B. B o d z i o c h - B ryła, ,Sfotografować wierszem” - w obszarach fascynacji młodej poezji. W: Poezja polska po 1939 roku wobec nowych mediów i nowej rzeczywistości. Kraków 2006. - G. B o r k o w s k a, Skrzypek z Abony. Uwagi o fotografii i literaturze najnowszej. W zb.: Co dalej, literaturo? Jak zmie- 
dobrze jako inspiracja, dopełnienie słowa, genologiczne wyzwanie, rodzaj wzbogacającego książkę paratekstu, ale także medium oddziałujące na poetykę i technikę tworzenia.

\section{..ppodlegać}

Pisarze - rzecz jasna - są również bohaterami fotografii ${ }^{18}$. Fotografii, która mimo swych tanatologicznych inklinacji ma przecież w końcu także przeczyć słynnemu stwierdzeniu Susan Sontag i frapującym analogiom Barthes'a ${ }^{19}$, odsyłać raczej do obecności niż nieobecności, być rodzajem łącznika między anonimowym z natury słowem a konkretnym ciałem. Kilka lat temu autor Fado przekonywał:

między pisarzem i jego dziełem zachodzi psychosomatyczny związek. Jedyną dopuszczalną formą książek powinny być serie zdjęć ich autorów. Nie komentarze, nie usprawiedliwienia i przedmowy [...], ale cykle przypadkowych, banalnych ujęć, pokazujących twarze, dłonie i sylwetki. Być może, oszczędziłoby to nam wielu rozczarowań po powrotach z księgarni ${ }^{20}$.

Tej opinii sekunduje Michał Paweł Markowski, który w komentarzu do albumu portretów Sławomira Mrożka stwierdza:

nie sposób zrozumieć jego twórczości bez patrzenia na jego twarz. Jestem głęboko przekonany, że to właśnie z tej twarzy wynika wszystko, co napisał, i że jego twarz pozwala to, co napisał, zrozumieć $^{21}$.

nia się wspótcześnie pojęcie i sytuacja literatury. Red. A. Brodzka-Wald, H. Gosk, A. Werner. Warszawa 2008. - C. Z a lew s k i, Pragnienie, poznanie, przemijanie. Fotograficzne reprezentacje w literaturze polskiej. Kraków 2010. Ta ostatnia pozycja, będąca, nawiasem mówiąc, pierwszym książkowym opracowaniem motywu fotografii w polskim literaturoznawstwie, zawiera bogatą bibliografię dotyczącą interesującego mnie tu zagadnienia.

${ }_{18}$ Historyczne omówienie różnych reakcji pisarzy na pojawienie się fotografii - począwszy od entuzjazmu (np. V. Hugo, W. Whitman, O. Wilde) po absolutny sceptycyzm, wiążący się z niechęcią do jakichkolwiek prób uwiecznienia swej osoby (J. Ruskin, E. Dickinson, G. Flaubert) - przynosi rozdział The Photography of Literature, zawarty w monografii F. B runeta Photography and Literature (London 2009).

19 S o n t a g (O fotografii. Przeł. S. M a g a la. Warszawa 1986, s. 69) skonstatowała: „Fotografia - to rejestr śmiertelności". Z kolei B a r t h e s z wynalazkiem fotografii łączy charakterystyczne dla kultury współczesnej wykluczenie śmierci z przestrzeni społecznej. Jak pisze (Światło obrazu, s. 156-157): „Fotografia musi mieć jakiś związek z »kryzysem śmierci«, rozpoczynającym się w drugiej połowie XIX wieku. Jeśli chodzi o mnie, wolałbym, aby zamiast umieszczać ciągle powstanie Fotografii w kontekście społecznym i ekonomicznym - pytać także o związek antropologiczny między Śmiercią i nową formą obrazu. Śmierć musi mieć przecież jakieś miejsce w społeczeństwie. [...] Fotografia - współczesna zanikaniu rytuałów - byłaby może odpowiednikiem wtargnięcia w nasze nowoczesne społeczeństwo Śmierci asymbolicznej, pozareligijnej, pozarytualnej, rodzajem nagłego zanurzenia się w Śmierci dosłownej”. Relacje między obrazem a śmiercią są przedmiotem bardzo ciekawego szkicu - inspirowanego głównie myślą M. Blanchota - autora Antropologii obrazu, H. B e 1 t i n g (Obraz i śmierć. Wcielenie we wczesnych kulturach. 〈Z epilogiem dotyczacym fotografii $\rangle$. Przeł. M. B r y l. Kraków 2007, s. 171-226). Koncepty teoretyczne można tu zresztą zderzyć z życiowym (czy raczej: śmiertelnym) konkretem. Oto bowiem istniał niegdyś osobny i prężnie rozwijający się gatunek określany mianem ,memorial photography” (inna nazwa to „memorial portraiture”), który śmierć danej osoby czynił elementarnym warunkiem uwiecznienia. Zmarłych (często był to ich pierwszy i ostatni zarazem kontakt z tym medium) poddawano jednak takim zabiegom inscenizacyjnym, aby jak najbardziej zniwelować grozę śmierci - dlatego oglądając tego typu zdjęcia, odbiorca ma wrażenie, że przedstawiają one raczej ludzi śpiących, a nie umarłych.

20 A. S t a s i u k, Twarz Samuela Becketta. W: Tekturowy samolot. Wołowiec 2000, s. 10.

${ }^{21}$ M. P. M a rk o w s k i, Nieobliczalne. W: Nieobliczalne. Eseje. Kraków 2007, s. 140. Rady- 
Opinii pisarza i badacza przeciwstawia się z kolei inny pisarz i badacz $\mathrm{w}$ jednym, a mianowicie Stefan Szymutko, deklarując:

Pisarze chyba nie powinni się fotografować, a twórcy pozytywistyczni nie powinni byli robić tego na pewno, choć żyli w okresie rozwoju fotografii [...]. Nic tak nie przeszkadza w czytaniu dzieł z tamtego okresu, jak zdjęcia ich twórców ${ }^{22}$.

Na zakończenie tego zaimprowizowanego naprędce dialogu - i zarazem dla zrównoważenia sił - warto przywołać jeszcze słowa Tadeusza Różewicza, który wiele lat wcześniej w swym tekście „,Teatralizacja” poezji, poetów i... innych ostrzegał:

Takie elementy jak wygląd zewnętrzny, urok, piękność lub szpetota postaci (autora) wywołują wśród publiczności różnorakie reakcje, które mają mało wspólnego z wartością odczytywanego utworu ${ }^{23}$.

Przywołuję niniejsze opinie nie po to, aby próbować rozstrzygać, kto z zacytowanych ma rację. Prawdę mówiąc, kwestia ta nie wydaje mi się nawet szczególnie doniosła, zważywszy, że w pewien sposób wszyscy oni mówią dokładnie to samo. Różnią się w ocenie zjawiska, ale zgodni są co do jego istoty. Żaden z nich przecież nie ma wątpliwości, iż publiczny wizerunek pisarza, jego fotografia nie jest - a przynajmniej nie musi być - czymś neutralnym i obojętnym dla odbioru dzieła. Innymi słowy, zdjęcie mówi i znaczy, natomiast lektura fotografii może wpływać na lekturę tekstu.

\section{Negatywy pozytywów?}

Większość badaczy zajmujących się interesującym mnie zjawiskiem podkreśla zgodnie: fotografia to medium polisemiczne i niewykluczone, że jedną z najważniejszych jej cech stanowi wieloznaczność. Sontag powiada: „Ostateczna mądrość obrazu fotograficznego kryje się w stwierdzeniu: oto powierzchnia. A teraz myślcie, a raczej czujcie to, co się pod nią kryje" ${ }^{24}$. Efektem owego namysłu jest zarówno wielość rywalizujących ze sobą perspektyw badawczych oraz języków

kalizm stwierdzenia autora Życia na miarę literatury można by łatwo wythumaczyć za pomocą praw rządzących poetyką eseju i za pomocą kontekstu, w jakim słowa te pierwotnie się pojawiły (album portretów Mrożka autorstwa A. N o w a k o w s k i e g o). Z drugiej strony, potraktowanie owej wypowiedzi tylko jako rodzaju chwytu retorycznego byłoby chyba jednak błędem. W końcu w zupełnie innym miejscu i przy zupełnie innej okazji M. P. Mark ow sk i (Proust i twarze. W zb.: Twarz. Red. A. Chojecki, S. Rosiek. Gdańsk 2000, s. 171) stwierdza: „Dyskurs na temat twarzy jest dyskursem par excellence hermeneutycznym. Widząc twarz, pytamy bowiem przede wszystkim o to, gdzie tkwi źródło jej sensu: czy kryje się na powierzchni, czy raczej musimy tę maskę rozbić, aby odkryć prawdę twarzy. Jest więc oczywiste, że twarz - choćby jako metafora - musi się pojawić tam, gdzie w ogóle pytamy o sens".

${ }^{22}$ S. S z y m u t k o, Trud pokrzepiania serc, albo samotność pozytywisty. W: Przeciw marzeniu? Jedenaście przykładów, ośmioro pisarzy. Katowice 2006, s. 34.

${ }^{23}$ T. R ó ż e w i c z, ,, Teatralizacja” poezji, poetów i... innych. W: Proza. T. 2. Kraków 1990, s. 239.

${ }^{24}$ S o n tag, op. cit., s. 26. Zob. też K. Ole chn ick i, Analiza i interpretacja fotografii. W: Antropologia obrazu. - S. S i k o r a, Kłopoty ze znaczeniem: „Powiększenie”. W: Fotografia. Między dokumentem a symbolem. - P. S z t o $\mathrm{m}$ p k a, Obraz fotograficzny jako przedmiot interpretacji. W: Socjologia wizualna. Fotografia jako metoda badawcza. Warszawa 2005. 
opisu (semiologii, socjologii, antropologii, psychoanalizy, historii sztuki, etc., etc. ${ }^{25}$ ), jak i różnorodność metafor, które pojawiają się w kontekście refleksji nad fotografią. Zestawienie ich z mnogością pisarskich wizerunków musi zaowocować stwierdzeniem, iż stworzenie jakiegoś uogólniającego modelu prezentacji, przynajmniej w przypadku artykułu, byłoby przedsięwzięciem tyleż ambitnym, co utopijnym. Nawet przy sporych obostrzeniach pozwalających znacznie ograniczyć ilość materiału - z jednym, acz istotnym wyjątkiem, interesować mnie tu będą przede wszystkim fotografie występujące na okładkach książek - zbyt duża jest różnorodność i zbyt wiele częstokroć niejasnych czynników trzeba by brać pod uwagę, aby stworzyć spójny, wymierny i klarowny katalog cech, jakimi można by operować tylko w odniesieniu do fotografii tej grupy ${ }^{26}$. Każde uogólnienie dałoby się tu zanegować jakąś egzemplifikacją, a każdy przykład - zastąpić kontrprzykładem. Płynący z tej diagnozy pesymizm epistemiczny ma na szczęście tylko połowiczne uzasadnienie. Brak jednolitej matrycy wizualnej (lub trudność jej odtworzenia) oraz zagrożenie wynikające z niebezpieczeństwa potraktowania tego, co epizodyczne, jako elementu reprodukowalnego, nie oznacza wszak, iż nie można wskazać pewnych tendencji i cech, które są charakterystyczne dla interesującej mnie tu grupy. Dalsze uwagi - dla przejrzystości i ekonomii wywodu-pozwoliłem sobie ująć w osobne i niekoniecznie powiązane ze sobą całostki. W większości przypadków bezpośrednią inspiracją do ich sformułowania była konkretna, acz reprezentatywna dla zjawiska, o którym mowa, fotografia wybranego pisarza.

\section{Twarz Zygmunta Krasińskiego}

W tym samym roku, w którym Felix Nadar zrobił niezwykły, by nie napisać: wstrząsający, portret Zygmunta Krasińskiego leżącego na łożu śmierci (można go zobaczyć w Muzeum Książąt Czartoryskich w Krakowie ${ }^{27}$ ), na łamach „American Journal of Photography" ukazał się tekst, w którym pojawia się taki oto passus:

Dzięki fotografii przyszły świat otrzyma wierny obraz naszych czasów. Przyszli studenci będą mogli ujrzeć prawdziwą skórę i prawdziwe oczy tych, o których życiu i dziełach będą czytać, chociaż ta skóra i te oczy już dawno zamieniły się w proch, podczas gdy studenci przewracają stronice historii ${ }^{28}$.

W ten sposób dawano wyraz funkcjonującemu przez długi czas przekonaniu - opartemu przede wszystkim na traktowaniu zdjęcia jako obrazu indeksowego

${ }^{25}$ Aby zachować konsekwencję w niekonsekwencji, świadomie będę odwoływał się do wielu z nich, co może, niestety, sprowokować zarzuty dotyczące podłoża metodologicznego tego szkicu.

${ }^{26}$ Te najciekawsze są zazwyczaj efektem bliskich relacji i przyjaźni między pisarzem a fotografikiem. Jako przykład niech posłużą zdjęcia jakie Ch. Bukowskiemu zrobił M. Montfort (wiele z nich można znaleźć w „Okolicy Poetów” $\langle 2002$, nr 10〉) czy fotografie Sontag wykonane przez A. Leibowitz (liczne, pokazujące autorkę Choroby jako metafory np. w trakcie chemioterapii, zawarte zostały w albumie A Photographer Life).

${ }^{27} \mathrm{Ci}$, którym bliżej do biblioteki niż do Krakowa, mogą zerknąć do drugiego wydania książki M. B i e ń c z y k a Czarny człowiek. Krasiński wobec śmierci (Gdańsk 2001) - na jej okładce widnieje właśnie to zdjęcie.

${ }^{28}$ „American Journal of Photography” 1858, nr 1, s. 148. Cyt. za: S t i e g l e r, op. cit., s. 60. Autorem tych słów jest prawdopodobnie H. Heine, acz opis bibliograficzny w książce S t i e g 1 e r a budzi pewne wątpliwości w tej kwestii. 
(oznaki) - iż fotografia jest medium idealnie przyległym do obiektu odniesienia, transparentnym, wiernym i obiektywnym, a wraz z jej rozpowszechnieniem historia reprezentacji już nigdy nie będzie taka sama ${ }^{29}$. Nie tylko zresztą o historię przedstawienia tu chodzi, lecz również o samą Historię, gdyż pojawienie się nowego medium miało pozwolić na bezpośredni wgląd w przeszłość i na niemal namacalny kontakt z tym, czego, co prawda, nie ma, ale za to było ${ }^{30}$. Na tym nie koniec. Oto bowiem cytowany fragment uruchamia jeszcze jeden kontekst, kolejny język, którego użycie ma w opisie interesującego mnie medium niemałą tradycję. Chodzi o taki typ spojrzenia, jaki nie chce $\mathrm{w}$ fotografii widzieć „trupa chwili”, nie chce kojarzyć jej ze śmiercią, lecz z życiem, z formą przezwyciężenia morderczego działania czasu, z technologicznym zmartwychwstaniem. To właśnie ten aspekt zdaje się fascynować np. Giorgia Agambena, który w Profanacjach stwierdza: „fotografia jest dla mnie w pewnym sensie miejscem Sądu Ostatecznego, przedstawia świat taki, jaki ukaże się w dniu ostatnim, w Dniu Gniewu" ${ }^{31}$. Tego typu konotacje i ufundowany na nich język niezwykle rzadko pojawiają się w odniesieniu do książek twórców żyjących, gdzie zdjęcie jest rodzajem podwojenia sygnatury ${ }^{32}$

29 Dobrym, bo literackim, przykładem owej wiary byłyby słowa C. Norwida, który w Czarnych kwiatach wyrażał przekonanie, że zdecydowanie lepszym niż pióro narzędziem zapisu tego, o czym będzie w swym tekście opowiadał, byłby dagerotyp. Wspomina o tym A. L u b a s ze w s k a w poświęconym relacji literatury i fotografii szkicu , $W$ daguerotyp raczej pióro zamieniam” („Teksty Drugie” 1999, nr 4, s. 165). Dziś ta „fikcja prawdy fotograficznej” - by posłużyć się określeniem A. R o u illé (Fotografia. Między dokumentem a sztuka współczesną. Przeł. O. H e d e m a n n. Kraków 2007, s. 68) - zdaje się mieć wielu oponentów. Przegląd różnych stanowisk badaczy dotyczących ontologii obrazu fotograficznego można znaleźć w jednym z rozdziałów książki R o u i 11 é (ibidem, s. 217-256).

30 Odwołuję się tu do tego, co B a r th e s (Światło obrazu, s. 138-139, 149) określił mianem neomatu fotografii (to-co-było): „Fotografia nie przypomina przeszłości [...]. W jej działaniu na mnie nie chodzi o odbudowanie tego, co runęło (w wyniku działania czasu, odległości), a jedynie o poświadczenie, że to, co widzę - naprawdę istniało”; „Być może, jest w nas nieprzezwyciężalny opór wobec wiary w przeszłość, w Historię, poza formą mitu. Fotografia po raz pierwszy wyłącza ten opór, przeszłość jest odtąd równie pewna jak teraźniejszość; to, co widzi się na papierze, jest równie pewne jak to, czego dotykamy".

${ }^{31}$ G. A g a m b e n, Profanacje. Przeł., wstęp M. K w a te r k o. Warszawa 2006, s. 35 . Nieco dalej autor Homo sacer precyzuje genezę tego zestawienia, stwierdzając: „Chrześcijańscy teolodzy często się zastanawiali (nie dochodząc zresztą do konkluzywnych wniosków), jak należy rozumieć zmartwychwstanie ciał. Czy ciało zmartwychwstanie w takiej kondycji, w jakiej znajdowało się w chwili śmierci (na przykład stare, łyse i chrome), czy też w pełni młodzieńczego rozkwitu? Orygenes przeciął ów spór, oznajmiając, że zmartwychwstaną nie tyle ciała, ile ich figura, eidos. W tym sensie fotografia to proroctwo, głoszące chwałę zbawionego ciała" (ibidem, s. 39). Podobne skojarzenia, choć, oczywiście, nieco inaczej uargumentowane, można również znaleźć w Świetle obrazu B a rth e s'a (s. 139): „Fotografia ma w sobie coś wspólnego ze zmartwychwstaniem. Czy nie da się o niej powiedzieć tego, co Bizantyjczycy mówili o obrazie Chrystusa, którym jest przepojony Całun Turyński, to znaczy, że to nie zostało zrobione ręką człowieka, acheïropoïétos".

${ }^{32}$ Zdarza się, iż to podwojenie staje się potrojeniem, w czym szczególnie gustują ci autorzy książek, dla których pisanie jest zajęciem dodatkowym (często incydentalnym), potencjalnemu czytelnikowi są zaś znani raczej z kina bądź z telewizji. Zdjęcia tego typu twórców - zupełnie jakby ich autorzy nie ufali słowu (nazwisku) - niemal obligatoryjnie pojawiają się na pierwszej stronie okładki, a zdarza się nierzadko, iż również i na czwartej. Przykładem tego typu „strategii” mogłyby być książki znanego z programu Top Gear J. Clarksona czy Spalony tost, autobiografia T. Hatcher, aktorki grającej w popularnym serialu Gotowe na wszystko. Oczywiście, tego typu egzemplifikacje dałoby się bez trudu rozbudować i odnieść do książek rodzimych celebrytów w rodzaju K. Rusin czy K. Cichopek. 
i elementem zaspokajającym ewentualną ciekawość (,a więc to tak wygląda skóra i oczy...”). Inaczej rzecz się ma w przypadku lektury fotografii pisarzy, którzy już odeszli. Tu zdjęcie również pełni funkcję poznawczą, bo przecież to dzięki fotografiom Julii Margaret Cameron wiem np., jak wyglądał Alfred Tennyson czy Thomas Carlyle, zdjęcia Nadara pozwoliły mi obcować nie tylko z malarskimi, ale i z fotograficznymi wizerunkami Charles'a Baudelaire'a, Gérarda de Nervala czy właśnie Krasińskiego (co mocniej niż daty w podręczniku uświadomiło mi, że wielu z lubianych przeze mnie twórców nie żyło wcale w jakiejś zamierzchłej przeszłości), a bez podręcznika Album du Surréalisme Mana Raya nasza wiedza o tej formacji byłaby jednak mimo wszystko uboższa. Równocześnie tego typu przedstawienia nie są zwykłymi, zaspokajającymi ciekawość zdjęciami (,A więc to tak wyglądała skóra i oczy...”), wypełniają bowiem pewien brak, nabierają charakteru substytutu, świadectwa czy śladu. Upraszczając nieco (żadne z tych pojęć nie jest w końcu synonimiczne i każde z nich domagałoby się osobnego potraktowania), można powiedzieć, iż tego rodzaju wizerunki idealnie oddają mortalno-wiwifikacyjną naturę fotografii, która pozwala na obcowanie z nieobecnym, stanowi świadectwo istnienia i nieistnienia zarazem. To „rozdarcie między wiwifikacją a mortyfikacją" ${ }^{33}$, zdaniem Stieglera, cechujące większości teorii fotografii, odpowiada w pewien sposób dyskusji nad miejscem podmiotu we współczesnym dyskursie teoretycznoliterackim, która od dłuższego czasu toczy się ,pomiędzy topiką funeralno-elegijną a topiką restytucyjno-rezurekcyjną" ${ }^{34}$. Czy fotografia w owej dyskusji mogłaby odegrać jakąkolwiek rolę? Niewykluczone, rzecz bowiem w tym, iż interesujące mnie medium - co niemal jednogłośnie podkreślają Walter Benjamin, Sontag i Barthes zdecydowanie mocniej niż jakikolwiek inny typ ikonograficznego przedstawienia upomina się o biografię, o jednostkowe istnienie, o konkretną podmiotowość. Widać to dobrze na przykładzie zestawienia zdjęcia i obrazu, jakiego Benjamin dokonuje $\mathrm{w}$ Matej historii fotografii. Oto w przypadku portretu malarskiego - pisze autor Pasaży - dopóki należy on do rodziny, dopóty budzi pytania o to, kogo przedstawia. Z upływem czasu uwaga oglądających zaczyna jednak coraz bardziej koncentrować się na kunszcie artysty, a coraz mniej na ukazanej postaci. Sztuka wygrywa więc tu z rzeczywistością, odniesienie zaś - ze swym przedmiotem. Inaczej dzieje się w przypadku fotografii, w której kontekście pojawia się „,coś, co wykracza poza świadectwo kunsztu fotografa, coś, czego nie da się zmusić do milczenia, co bez najmniejszego gestu dopomina się o imię tej, która kiedyś tam żyła, a tutaj jeszcze jest rzeczywista i nigdy nie zechce przejść do s z t u k i całkowicie" "35. Konstatację Benjamina można by uzupełnić słowami autora Światta obrazu, przekonującego,

${ }^{33}$ Zob. Sti e gle r, op. cit., s. 248: „Rozdarcie między wiwifikacją i mortyfikacją, między zdolnością fotografii z jednej strony do ożywiania martwego i przypisywaną jej umiejętnością przemiany istot żywych w sztywne, martwe obrazy z drugiej strony, stanowi rys podstawowy teorii fotografii - od jej początków po współczesność".

${ }^{34}$ Zob. A. Z a w a d zk i, Zarysowanie autora. W: Literatura a myśl słaba. Kraków 2009, s. 233: „Śmierć i powrót, wygnanie i powrót - pomiędzy topiką funeralno-elegijną a topiką restytucyjno-rezurekcyjną zdaje się krążyć, niczym wahadło, teoretyczna refleksja nad literackim podmiotem od lat ponad trzydziestu. Przy czym gest wygnania autora z tekstu okazał się łatwiejszy niż wysiłek jego przywrócenia i ponownego wprowadzenia kategorii podmiotu do dyskursu o literaturze czy, szerzej, kulturze".

${ }^{35}$ W. B e n j a m i n, Mała historia fotografii. W: Anioł historii. Eseje, szkice, fragmenty. Wybór, oprac. H. Orło w sk i. Przeł. J. S i k or s ki. Poznań 1996, s. 108. 
iż fundamentalną cechą fotografii, jej noematem ,jest fakt, że ktoś ujrzał odniesienie (nawet gdy chodzi o przedmiot) z krwi i kości oraz że było ono we wła s n ej o s o b i e. Fotografia rozpoczęła się zresztą historycznie jako sztuka Osoby: jej tożsamości, jej pozycji, co można by nazwać (w każdym znaczeniu tego wyrażenia) od c zucie m wła s nej tożs a mości przez ciało" ${ }^{36}$.

Rzecz jasna, ten aspekt interesującego mnie tu medium nie uwidacznia się tylko na zdjęciach osób parających się piórem. Czy istnieje jednak coś, co mogłoby je wyróżniać? Gdybym miał zaryzykować pozytywną odpowiedź na to pytanie, stwierdziłbym, iż podwójna natura fotografii koresponduje z dwojaką naturą języka, który z jednej strony - jak chce Barthes - niszczy każdy podmiot, lecz z drugiej, jeśli tylko słowa są wystarczająco mocno naznaczone sygnaturą, ocala autora, nie pozwala mu pójść w zapomnienie. W tym kontekście widniejąca na okładce książki fotografia twórcy przypomina - proszę wybaczyć oczywistość tej konstatacji, ale jest to oczywistość, którą osoby zawodowo trudniące się literaturą z jasnych dla wszystkich powodów wypierają z pamięci ${ }^{37}$ - iż za podmiotem/narratorem kryje się jakiś inny, za światem przedstawionym - pewien świat realny, za słowem zaś - ciało. To przypomnienie stanowi równocześnie napomnienie, gdyż z tej perspektywy lektura zdjęcia wydaje się aktem tyleż poznawczym, co etycznym. Nie ma tu bowiem mowy o powrocie autora, który za sprawą swej podwojonej sygnatury na nowo stawałby się figurą władzy czy instancją kontrolującą oraz nadrzędną wobec czytelnika. Jest natomiast rodzaj sygnatury, który, podobnie jak inne rozproszone $\mathrm{w}$ tekście ślady ${ }^{38}$, może być rodzajem biografemu.

\section{Księgarenka Ewki Lipskiej}

Jak nazywał się pierwszy pisarz, który stanął przed obiektywem aparatu? Kto stał po drugiej stronie? Kiedy i gdzie miało to miejsce? Tego typu pytania, choć frapujące z punktu widzenia historii, z perspektywy semiotycznej wydają się mało istotne. Zdecydowanie ważniejsza jest tu mnogość pisarskich wizerunków, której efektem jest utrwalenie się w świadomości odbiorców określonej doksy przedstawienia. Jej genezy - co pokazała Joanna Guze w swym szkicu poświęconym portretom pisarzy ${ }^{39}$ - należałoby szukać przede wszystkim w renesansowym ma-

${ }^{36} \mathrm{~B}$ a r th e s, Światto obrazu, s. 134. Warto w tym miejscu przypomnieć równie znane stwierdzenie S o n t a g (op. cit., s. 141): ,zdjęcie - to nie tylko obraz (jako dzieło malarskie), interpretacja rzeczywistości, ale także ślad, coś odbitego bezpośrednio ze świata, niczym odcisk stopy albo maska pośmiertna".

${ }^{37}$ Zob. J. B e r g e r, Użycia fotografii. W: O patrzeniu. Przeł. S. S i k o r a. Warszawa 1999, s. 74: „Co zastępowało fotografię, nim wynaleziono aparat fotograficzny? Odpowiedź, której można by oczekiwać, brzmi: rycina, rysunek, obraz malarski. Jednak bardziej odkrywcza odpowiedź brzmiałaby: pamięć". Stąd już tylko krok do stwierdzenia, że - być może - i ten wynalazek, podobnie jak pismo, jest rodzajem pharmakonu.

${ }_{38}$ Do takiego ujęcia kwestii w znacznym stopniu zainspirowały mnie uwagi dotyczące słabej ontologii podmiotu literackiego sformułowane przez Z aw adzki e g o (op. cit., s. 233-241), a oparte na koncepcjach G. Vat t i m a (Filosofia al presente. Milano 1990), J. D e r rid y (Memoirs of the Blind: The Self Portrait and the Other Ruins. Transl. P.-A. B r a u lt, M. N a a s. Chicago-London 1993) oraz J.-L. N a n c y'e g o (Le Regard du portrait. Paris 2000).

39 J. Gu ze, Laur dla pisarza. W: Twarze z portretów. Warszawa 1974. Pierwsze tego typu przedstawienie autorka pokazuje już na przykładzie pochodzącej z 2500 r. p.n.e. rzeźby egipskiej, 
larstwie, choć dopiero fotografia - ze względu na swą powszechność i łatwość powielania - odpowiednio ją skodyfikowała. W efekcie większość czytelników myśląc o zdjęciu pisarza ma jasno sprecyzowane wyobrażenie tego, co powinno się na nim pojawić. Można by zaryzykować tezę, iż ważny jest tu nie tyle wizerunek konkretnej osoby, ile umiejętne przekształcenie go w nie podlegającą żadnej dyskusji personifikację Pisarza czy alegorię Literatury jako takiej. Wykreowaniu swoistego signifié ,pisarskości” służyć ma zarówno dobór odpowiednich atrybutów (okulary, książka trzymana $\mathrm{w}$ ręce, pióro, maszyna do pisania), miejsca (biurko, w tle biblioteka), pozy (zafrasowana lub lekko uśmiechnięta twarz, ręka podpierająca policzek, spojrzenie skierowane gdzieś w dal) czy sytuacji (pisarz czytający tekst dla zasłuchanej publiczności bądź sygnujący swą książkę na spotkaniu autorskim etc.). Niezależnie, czy zinterpretujemy tak zaaranżowane fotografie jako symptom zapobiegliwości lub lęku (pisarstwo rzadko zapewnia rozpoznawalność, więc częstokroć dopiero odwołanie się do atrybutów profesji gwarantuje odpowiednią identyfikację), jako efekt bezrefleksyjnego powtórzenia czy wręcz odwrotnie jako świadomy gest wynikający ze znajomości ikonografii i rządzącego nią kodu - zdecydowana większość autorów ma tego typu zdjęcia w swym portfolio.

Stereotypowość i schematyczność opisanych obrazów tyleż zobowiązuje, co i prowokuje. W rezultacie można znaleźć sporo zdjęć korzystających, co prawda, ze wspomnianej rekwizytorni, ale na różne sposoby ją modyfikujących. Rzecz jasna, nie chodzi mi tu tylko o wariantywność rozwiązań, lecz o swoistą pastiszowość/parodyjność tego rodzaju przedstawień. Ciekawą egzemplifikacją takich zabiegów wydaje się np. fotografia Ewy Lipskiej zamieszczona na okładce tomu $J a^{40}$. Tym razem poetka - która, jak pokazują inne książki i poświęcona jej strona internetowa, ma w swym archiwum również klasyczne pisarskie portrety - zdecydowała się zafundować swym czytelnikom niespodziankę w postaci zdjęcia pochodzącego z okresu wczesnego dzieciństwa. Wzruszające? Zabawne? Zaskakujące? Ale niewykluczone, iż to raczej wyraz smutnego przekonania, że w pewnym wieku lepiej nie pokazywać swej twarzy. Style odbioru tej fotografii mogą być, rzecz jasna, bardzo różne, bo też zdjęcie owo, wbrew pozorom, wydaje się niezwykle wieloznaczne. Oto bowiem umieszczona na tomiku poezji twarz autora z czasów dzieciństwa wygląda tyleż na objaw infantylizmu, ile na przekorną grą $\mathrm{z}$ zakorzenionym w kulturze przekonaniem o istnieniu duchowego pokrewieństwa między postaciami poety i dziecka. Nieprzypadkowe jest także miejsce, w którym ta fotografia została zrobiona - tuż za opatuloną w grube futerko dziewczynką widać wszak witrynę księgarni. W tym kontekście równie dobrze można to zinterpretować jako żartobliwą zapowiedź dalszych losów przyszłej poetki (fotografia

\footnotetext{
acz renesans, ze względu na niezwykły kult literatury i jej twórców, w historii tego typu reprezentacji wydaje się epoką wyjątkową. Z kolei XIX w. był chyba ostatnim okresem, kiedy uznany pisarz miał szansę na profesjonalny portret zarówno malarski, jak i fotograficzny. Casus Baudelaire'a, którego malował G. Courbet, rysował É. Manet, a fotografował F. Nadar, raczej się już nie powtórzy. Swoją drogą - acz to już uwaga czyniona na marginesie, bo dotycząca historii portretu w ogóle - fotografia przejęła nie tylko schemat przedstawienia, ale i... klienta. Oto bowiem, jak przekonuje B e n j a m in (op. cit., s. 112): „Ofiarą fotografii padło właściwie nie malarstwo pejzażowe, lecz miniatura portretowa".

${ }^{40}$ E. L i p s k a, Ja. Kraków 2003. Wykorzystane na okładce zdjęcie - jak informuje wydawca - pochodzi z prywatnego archiwum autorki.
} 
miałaby więc ujawniony po latach charakter profetyczny), jak i przekorną grę z tysiącem zdjęć pokazujących nobliwych pisarzy w otoczeniu książek.

\section{Papieros Andrzeja Stasiuka}

Gest repetycji, rzecz jasna, nie musi oznaczać braku wyobraźni. Może być natomiast - w końcu każdy rytuał oparty jest na powtórzeniu - najprostszym sposobem ewokacji przeszłości, uruchomieniem kulturowego kodu, przywołaniem określonej tradycji. Aluzja, cytat, trawestacja, stylizacja i inne klasyczne środki służące prowadzeniu tekstowego dialogu, a wymieniane w każdym podręczniku poetyki - jak pokazuje chociażby Gui Bonsiepe ${ }^{41}$ - mogą mieć swój wizualny odpowiednik. W świetle tego schematyczność pisarskich przedstawień wolno odczytać równie dobrze jako oznakę braku kreatywności, jak i jako świadomy gest służący zaakcentowaniu przynależności do tej, a nie innej profesji. Naturalnie, akurat tego typu odwołanie jest czymś absolutnie jasnym, niemal banalnym, nie pozostawiającym żadnych niedomówień. Na szczęście, podobnie jak w literaturze, i w tej przestrzeni zdarzają się relacje bardziej subtelne, ukryte, nie tak oczywiste. Dobrą egzemplifikacją takiego rodzaju zabiegu mogłoby być zdjęcie Andrzeja Stasiuka widniejące na tytułowej stronie tomu opowiadań Przez rzekę ${ }^{42}$. Pozornie, $\mathrm{w}$ warstwie denotacyjnej, fotografia jest bardzo prosta - klasyczny portret, zbliżenie twarzy pisarza, który patrzy gdzieś w przestrzeń, w ustach zaś trzyma dopalającego się papierosa. Ten drobny detal - żarzący się papieros ${ }^{43}$ - wydaje się tu jednak szczególnie istotny, to właśnie on otwiera bowiem całe pole kulturowych skojarzeń.

Benjamin w Ulicy jednokierunkowej przekonywał: „Gdyby papierosowy dym $\mathrm{w}$ fifce $\mathrm{i}$ atrament $\mathrm{w}$ piórze ciągnęły się równie lekko, byłbym $\mathrm{w}$ arkadii mojego pisania" ${ }^{44}$. Zmarszczone czoło i zasępiony wzrok Stasiuka nie sugerują jednak wcale zadowolenia czy szczęścia będącego pochodną radości pisania bądź efektem postawienia finalnej kropki. Może dlatego, że zarówno wyraz twarzy, jak i trzymany w ustach papieros ma najprawdopodobniej odsyłać do innego, acz bardzo dobrze rozpoznawalnego kodu. Kodu, w którym palenie - jak wszechstronnie pokazują autorzy prac na temat jego historii - było ,szczególnie użytecznym sposobem charakteryzacji środowiska intelektualistów" ${ }^{45}$, a wizerunek artysty palą-

${ }^{41}$ G. B o n s i e p e, Retoryka wizualno-werbalna. W zb.: Ut pictura poesis. Red. M. Skwara, S. Wysłołuch. Przeł. M. B. F e d e w i c z. Gdańsk 2006.

42 A. Stas i u k, Przez rzekę. Czarne 1996. Twórcą fotografii jest M. Strzałk o w s ki. Warto zwrócić uwagę - choć oczywiście nie stanowi to dziś żadnej reguły - iż zdjęcie autora nie pojawiło się, jak często bywa, w lewym górnym rogu tylnej strony okładki, lecz na stronie pierwszej. Bardzo ciekawą analizę medialnych wizerunków pisarzy - w tym fotografii Stasiuka - przeprowadziła D. Róży cka (Autorzy $i$ ich maski. O fotografiach pisarzy współczesnych. W zb.: Teatr wielki, mniejszy i codzienny. Red. P. Kowalski. Opole 2002). Niniejszy szkic sporo tej pracy zawdzięcza.

43 Być może, to fakt niegodny uwagi, ale książkę Stasiuka rekomendował na okładce M. Ś w i e t 1 i c k i, a więc poeta, który z papierosa uczynił swój znak rozpoznawczy - wystarczy przywołać tytuł jednego z jego tomów oraz zerknąć na ostatnią stronę Schizmy.

44 W. B e n j a m i n, Ulica jednokierunkowa. Przeł. A. K o p a c k i. Warszawa 1997, s. 36.

45 B. Te m p e 1, Symbolika i obrazowanie: palenie w sztuce poczawszy od XVII wieku. W zb.: 
cego papierosa stawał się symbolem zarówno „pogrążenia się w kontemplacji” 46 i ,niezależności ducha"47, jak i wyrażania nieprzystosowania społecznego i konfliktu pokoleń ${ }^{48}$ oraz ,egzystencjalnej rozpaczy" ${ }^{49}$. Jak widać, projektowane w ten sposób pole odwołań jest nie tylko rozległe, ale przede wszystkim atrakcyjne z punktu widzenia artystycznych mitologii. A raczej byłoby takie, gdyby nie fakt, iż antynikotynowa moda lat dziewięćdziesiątych XX wieku swym zasięgiem objęła również pisarzy. W efekcie ludzie pióra - nawet jeśli w rzeczywistości wcale nie rzucili nałogu - z papierosem zaczęli się fotografować niezwykle rzadko, czego najlepszym przykładem album Krajobrazy literackie, gdzie wśród 200 portretów są zaledwie trzy takie zdjęcia ${ }^{50}$. Stasiuk, decydując się na publikację tego typu portretu, nie ryzykował, rzecz jasna, żadnego społecznego odium, ale też odwoływał się do kodu, który w wyniku przemian kulturowych stracił wiele ze swej niedawnej świetności. Jak więc ten gest wytłumaczyć? Niewiedzą? Przekorą? Chęcią zamanifestowania swej niechęci wobec uwarunkowań społecznych? A może raczej uznać ten wybór za sygnał, iż duchowo i artystycznie bliższa jest mu przeszłość? Każda z sugerowanych odpowiedzi wydaje się prawdopodobna, ale tylko ostatnia znajduje potwierdzenie w analizie dokonanej przez znawcę twórczości Stasiuka. Oto bowiem fotografia autora Fado - co pokazuje tyleż dociekliwa, ile nieco złośliwa interpretacja Dariusza Nowackiego - to przede wszystkim rodzaj wizualnego cytatu, konotującego konkretniejszy i bardziej materialny typ odniesień:

zdjęcie zdobiące okładkę Przez rzekę [...] jest aluzją do znanej serii zdjęć przedstawiających Marka Hłaskę, wykonanych w 1959 roku w Izraelu. A zatem już na wstępie czytelnik ma prawo czuć się zaniepokojony: czyżby wyrób hłaskopodobny [...]? [...]

[...] nie można [jednak] powiedzieć, że autor Białego kruka to zwykły hłaskoid, jak zwykli mawiać osobnicy niechętni beskidzkiemu pisarzowi. Po pierwsze, aluzja z okładki ma bardziej złożoną naturę: Stasiuk kopiuje Hłaskę, ten kopiował Jamesa Deana, a kogo kopiował Dean? Zapewne kogoś. Tak więc to nie tylko kopia kopii, to kopia bez oryginału. [...] Po drugie, komentowane tu zdjęcie zawiera jednak pewien istotny sygnał niezgodności, zerwania z reprodukcją i symulacją. Sfotografowany Stasiuk trzyma w ustach „nieprawidłowego” papierosa, papierosa-hańbę, który wyklucza go z grona twardzieli, hłaskoidalnych ajron-menów. Stasiukowy papieros jest z filtrem! Może przez nieuwagę, a może zupełnie świadomie - tak czy owak, mit został nadgryziony, otwarcie zamanifestowano dystans wobec mitu ${ }^{51}$.

Dym. Powszechna historia palenia. Red. S. L. Gilman, Z. Xun. Przeł. J. S o c h o ń - J a s n o r z e ws k a. Kraków 2009, s. 210.

46 Ibidem.

${ }^{47}$ Ibidem.

48 Ibidem, s. 215.

49 N. I s e n b e r g, Dym w kinematografii: od Weimaru do Hollywood. W zb.: Dym, s. 252.

${ }^{50}$ Zob. E. L e m p p, Krajobrazy literackie. Fotografie 1985-2007. Kraków 2008. Z papierosem na zdjęciu pojawia się tam M. Świetlicki i R. Przybylski, z fajką zaś J. J. Szczepański. Gdyby analogiczny album wydano w latach sześćdziesiątych czy siedemdziesiątych w. XX, najprawdopodobniej proporcje wyglądałyby zupełnie inaczej.

51 D. N o w a c k i, Zawód: czytelnik. Notatki o prozie polskiej lat 90. Kraków 1999, s. 88-89. Swoją drogą, liczba papierosów, które wypalają bohaterowie prozy Stasiuka, nie jest tu chyba bez znaczenia. Dla autora książki Jak zostałem pisarzem. (Próba autobiografii intelektualnej) (Czarne 1998) - nawet jeśli wziąć pod uwagę jej mocno ironiczny charakter - sam akt palenia również zdaje się mieć spore znaczenie, skoro papierosy tyle miejsca zajmują w jego wspomnieniach. Oto na pierwszych stronicach tej książki (s. 9-10) znajdujemy taki fragment: „Papierosy caro były w miękkich błękitnych paczkach. Kosztowały dwadzieścia złotych. Klubowe cztery pięćdziesiąt. To był poważny rozrzut. Dzisiaj już tak nie ma. Najchętniej paliliśmy extra mocne bez filtra, bo bardziej 
Że pierwotne skojarzenie krytyka było zgodne z intencją pisarza (choć pewnie dalsza interpretacja już niekoniecznie), 2 lata później potwierdziła wydawnicza rzeczywistość. Oto w kolejnej edycji książki Stasiuk nie tylko zrezygnował z omówionego zdjęcia, ale też zastąpił je radykalnie odmiennym: na okładce znów pojawia się autor i znów jest to fotografia zajmująca jej całą pierwszą stronę ${ }^{52}$, tym razem wszakże twórca, ubrany w białe śpioszki, prezentuje się swemu czytelnikowi jako niewinny malec: uśmiechnięty chłopczyk idzie w stronę aparatu, jak gdyby przekorny autor chciał w ten sposób pokazać, że oto i tak można wejść do literatury.

\section{Oko Georges'a Bataille'a}

Etymologia słowa „twarz” odsyła do starocerkiewnego rzeczownika „twar”, czyli 'dzieło', czego łacińskim odpowiednikiem byłby związek między leksemami ,facies" ('twór, twarz') i ,facere" ('tworzyć'). Twarz jest więc wytworem, czymś wykreowanym, jednym słowem - dziełem, którego odczytanie, analogicznie jak w przypadku każdego innego dzieła, wymaga odpowiednich narzędzi, kompetencji i wiedzy. Marzenie o zupełnie osobnej nauce poświęconej tylko twarzy i sposobom jej interpretowania, przyświecało zarówno Arystotelesowi, renesansowym fizjonomistom, jak i XVIII- i XIX-wiecznym uczonym w rodzaju Johanna Kaspara Lavatera i Franza Jozefa Galla ${ }^{53}$. Jeden ze znawców tego zagadnienia pisze: „Twarz we frenologii traktowano jako tekst, który jest wprawdzie pisany innym niż język pismem, ale można nauczyć się go czytać" ${ }^{54}$. Jego opanowanie miało dawać możliwość odkrycia taksonomii i typologii obejmującej całe ludzkie uniwersum, acz szczególnym zainteresowaniem ówczesnych uczonych cieszyły się jednostki wybitne, a więc również ludzie parający się piórem. Oto przykładowa próbka tego typu lektury - lektury twarzy pisarza, który, jak wiadomo, był niezwykłym entuzjastą fizjonomiki i jej potencjału:

szkodziły. Potem gdzieś znikły i musieliśmy się zadowalać byle czym. Ale zanim przepadły, kosztowały chyba najpierw sześć pięćdziesiąt, a potem dziesięć. Żółty pasek i czarne litery. [...] Wierzyliśmy, że mają coś wspólnego z gitanesami. Nie miały. Teraz to wiem".

${ }^{52}$ Książka ukazała się 2 lata później, autorem zdjęcia zaś był J. S t a s i u k. Gwoli ścisłości trzeba powiedzieć, że temu wydaniu towarzyszyły dwa zdjęcia. Na czwartej stronie okładki Stasiuk powtórzył, tym razem w zminimalizowanej skali, reprodukcję tej poprzedniej.

${ }^{53}$ Zob. J. B a c hó r z, O twarzach wedlug fizjonomistów (fragmenty). W zb.: Twarz. - J. L im o n, Czytanie twarzy. W zb.: jw. Fizjonomika (szczególnie w swej XIX-wiecznej odmianie) wywierała spory wpływ na ówczesnych pisarzy i literaturę. $Z$ jednej strony, mielibyśmy dużą grupę ludzi pióra zafascynowanych koncepcjami Galla niejako ma marginesie swych głównych zatrudnień, z drugiej - można również mówić o realnym oddziaływaniu frenologii na sposoby kreacji bohaterów literackich. O jednym i drugim aspekcie zagadnienia interesująco pisze $\mathrm{B}$ a c hó r z.

${ }^{54} \mathrm{Limon}$ op. cit., s. 106. Jak przekonują J.-J. Courtine i C. Haroche (Historia twarzy. Wyrażanie i ukrywanie emocji od XVI do poczattu XIX wieku. Przeł. T. S w o b o d a. Gdańsk 2007, s. 7): „Od wieku XVI do XVIII podręczniki retoryki, prace z zakresu fizjonomiki, książki o ogładzie i sztuce konwersacji niestrudzenie przypominają: twarz jest najważniejszym elementem postrzegania siebie, wrażliwości na drugiego człowieka, społecznych rytuałów i polityki. To pozostałość po starożytnych, nabierająca jednak na początku XVI stulecia nowego znaczenia. Wszystkie teksty odmieniają i powtarzają jedno twierdzenie: twarz mówi. A dokładniej: człowiek wyraża się za pomocą twarzy. Zarysowuje się wyraźnie pewien związek między podmiotem, językiem i twarzą; związek kluczowy dla zrozumienia nowożytnej osobowości". 
Twarz wielkiego człowieka zawsze nosi na swym obliczu dowód uwierzytelniający jego pełnomocnictwo w oddziaływaniu na ludzkość. [...] Otwarty, sprawny i bystry rozum jest ukryty pod linią ciągnącą się od czoła do brwi. Wrażenie tego czoła zostaje jednak z kolei osłabione przez niezbyt wydłużoną krzywiznę zgięcia ciągnącego się od brwi aż do nasady nosa.

$[\ldots]$

Nos w pełni wyraża sprawność duchową, smak artystyczny i miłość, to znaczy wzniosłość i poetyczność.

Przejście od nosa do ust, szczególnie górna warga, graniczy z dostojeństwem, szlachetnością i także jest przejawem poetyckiego daru i zdolności poetyckiego tworzenia ${ }^{55}$.

Nie chodzi tu więc, jak chociażby w przypadku dzisiejszych specjalistów zajmujących się językiem ciała, o odczytanie z układu ust stanu psychicznego, a z wyrazu oczu - przeżywanych właśnie emocji, lecz o dotarcie znacznie głębiej, wprost do istoty osobowości, do jądra stanowiącego tożsamość obserwowanego. Tego typu ambicja stworzenia ogólnej matrycy pozwalającej na podstawie kształtu głowy oraz rysów twarzy opracowywać portrety psychologiczne jednostek i w ten sposób otrzymywać klucz do wyjaśniania ludzkich decyzji i postępowania, znalazła $\mathrm{w}$ fotografii nadspodziewane wsparcie ${ }^{56}$. Oto bowiem pojawiło się medium, którego istotą, jak uważano ${ }^{57}$, jest neutralność dająca gwarancje obiektywności, a rolą - by posłużyć się określeniem André Rouillé - ,wytwarzanie widzialności dostosowanej do nowych czasów" ${ }^{58}$. Co więcej, technologiczne możliwości związane z jej umiejętnością zatrzymania ruchu, uchwycenia najdrobniejszego detalu i wyodrębnienia pojedynczego gestu lub miny kusiły obietnicą zobaczenia czegoś,

55 J. C. Lavater, Fragmenty fizjognomiczne. W zb.: Maski. Wybór, oprac., red. M. J an i o n, S. R o s i e k. T. 1. Gdańsk 1986, s. 31 (przeł. K. To e plitz). Przedmiotem przytoczonego tu opisu była twarz J. W. Goethego.

${ }^{56}$ Jak przekonuje A. S e k u la w swym szkicu omawiającym szczegółowo powiązania fotografii i frenologii w kontekście powstawania nowej koncepcji archiwum (Ciało i archiwum. W: Społeczne użycia fotografii. Przeł. K. P i j a r s k i. Warszawa 2010, s. 143): „Nie zrozumiemy [...] właściwie kultury portretu fotograficznego, jeśli nie weźmiemy pod uwagę ogromnego prestiżu i popularności paradygmatu fizjonomicznego w latach 40. i 50. XIX wieku. Zwłaszcza w Stanach Zjednoczonych popularyzacja fotografii i frenologii nałożyły się na siebie". Najbardziej wymownym tego dowodem - pokazującym zarówno skalę zjawiska, jak i jego powszechny charakter - była niemal obligatoryjna powinność dołączania zdjęcia wraz z analizą frenologiczną do aplikacji o pracę.

57 W roku 1839 J. J a n in w tekście zatytułowanym La Daguerotype przekonywał czytelników pisma „L'Artiste” (1938, nr 11. Cyt. za: A. R o u il1 é, Fotograficzna nowoczesność. W: Fotografia. Między dokumentem a sztukq wspótczesną, s. 26): „Wyobraźcie sobie tylko, że lustro zachowuje odbicie wszystkich przedmiotów, które się w nim odbijają, a wówczas zrozumiecie nieomal w pełni, czym jest tak naprawdę dagerotyp". 100 lat później - tym razem już w odniesieniu do klasycznej fotografii - A. B a z in (Ontologia obrazu fotograficznego. W: Film i rzeczywistość. Wybór, przeł., posł. B. M i c h a ł e k. Warszawa 1963, s. 14) stwierdzał z kolei: „Oryginalność fotografii w stosunku do malarstwa polega tedy w swej istocie na obiektywizmie. Nic więc dziwnego, że zespół soczewek, który stanowi »oko fotograficzne«, zastępujące oko człowieka, nosi nazwę »obiektywu«". Omówienie tego aspektu fotografii można znaleźć np. w szkicach K. O le c hn i cki e g o (Fotografia: cytat z rzeczywistości czy parafraza? O dylematach fotograficznego realizmu. W: Antropologia obrazu), S. S i k o r y (Ktopoty z fotografia. W: Fotografia. Między dokumentem a symbolem), A. R o u illé (Prawda fotografii. W: Fotografia. Między dokumentem a sztuka wspótczesna) i M. A. P ot o c k i e j (Prawda w fotografii. W: Fotografia. Warszawa 2010).

${ }^{58} \mathrm{R}$ ou illé, Fotograficzna nowoczesność, s. 33. Jak pisze autor (ibidem, s. 33-34): „Jako swoista maszyna do widzenia, fotografia pojawia się w chwili, gdy ludzkie oko, a także i oko artysty, okazało się niewystarczające wobec rozległej, obszernej i niezwykle złożonej rzeczywistości, która rozwija się w coraz szybszym tempie". 
czego nieuzbrojone w obiektyw oko dotąd w żaden sposób zobaczyć nie mogło. Stąd już tylko krok - na co zwracał uwagę Benjamin - do zestawienia profesji fotografa i psychoanalityka, gdyż zarówno jeden, jak i drugi odsłania przed nami to, co ukryte i nieuświadomione ${ }^{59}$. W omawianym przypadku tym, co ukryte i nieuświadomione, a więc tym, co należałoby uświadomić i odkryć, nie byłaby tylko relacja między zewnętrzem a wnętrzem, między fizjonomią a osobowością, lecz nadbudowany nad nią jeszcze jeden poziom, gdzie twarz byłaby istotnym odniesieniem interpretacyjnym utworu, a jej mowa znajdowałaby odzwierciedlenie $\mathrm{w}$ języku dzieła. Z dzisiejszej perspektywy rysujący się w ten sposób projekt hermeneutyki opartej na kompatybilności dwóch rodzajów pisma (dla pierwszego materią jest atrament, dla drugiego - światło) - by skorzystać z greckiej etymologii słowa „fotografia" ${ }^{60}$ - był tyleż ambitny, ile utopijny, o czym najlepiej świadczy to, co z niego zostało. Cóż bowiem? Prężnie rozwijające się - choć częstokroć traktowane $\mathrm{z}$ dystansem - różne odmiany studiów body languages, których reprezentanci zdecydowanie wolą jednak koncentrować się na odczytywaniu tego, co w człowieku zmienne, niż tego, co stałe. Ponadto: naukowy sceptycyzm, ufundowany na przekonaniu, iż zdjęcie jest przede wszystkim elementem identyfikującym, a wszelkie próby nadbudowania nad nim jakiejś prawdy dotyczącej wnętrza portretowanej osoby są tyleż subiektywne, co ryzykowne. W efekcie współczesne próby łączenia fizjonomii z tożsamością, tej drugiej zaś z dziełem, jeśli w ogóle się pojawiają, to sytuują się na marginesie akademickich zatrudnień i traktowane są przede wszystkim jako pokazy swoistej gry wyobraźni. Gry nie pretendującej na pewno do miana naukowej, ale też w jakiś sposób fascynującej, bo chyba tak można by określić próby powiązania niechęci Franza Kafki do fotografowania się z profilu z tajemnicami jego osobowości i z niejasnością prozy ${ }^{61}$; szukanie analogii między odnotowaną za pomocą fotografii utratą wagi ciała Becketta a pisaniem

${ }^{59}$ B e n j a m in (Mała historia fotografii, s. 109) przekonywał: ,zupełnie inna natura przemawia do kamery niż do oka, inna przede wszystkim w tym sensie, że miejsce przestrzeni spenetrowanej świadomością człowieka zajmuje przestrzeń ogarnięta podświadomie. I jakkolwiek tak już jest, że człowiek choćby tylko z grubsza uświadamia sobie na przykład chód ludzi, to jednak już z pewnością nic nie wie o ich postawie w ułamku sekundy s t a w i a n i a k ro k u. Odkrywa go przed nim fotografia ze swoimi środkami pomocniczymi, jak ruch zwolniony czy powiększenie. Dopiero dzięki niej poznaje on zjawiska optycznie wymykające się świadomości, tak jak o podświadomych popędach dowiaduje się dzięki psychoanalizie". Z kolei F. S o u la g e s, pisząc o zdjęciach portretowych $(\mathrm{Od}$ przedmiotu portretu do ogólnego przedmiotu fotografii: ,to, co zostało odegrane”. W: Estetyka fotografii. Strata i zysk. Przeł. B. M y t y c h-F o r a j t e r, W. F o r a j t e r. Kraków 2007, s. 81) stwierdzał: „Zdjęcie stanowi przede wszystkim wypadkową związków pomiędzy sferami nieświadomości uczestników, między ich popędami. [...] W przypadku każdego fotografa toczy się nieświadomie dialektyczna gra pomiędzy jego »ja « dążącym do panowania i organizacji, id, które w znacznej mierze wyraża jego popędy oraz dążenie ku rzeczywistości zewnętrznej (a więc: ku fotografowane$\mathrm{mu}$ i fotografii), oraz superego, przepełnionym zagadkową identyfikacją fotografa $\mathrm{z}$ »wielkimi« fotografami, a więc: z regułami oraz modelami estetycznymi, stylistycznymi i technicznymi".

60 „Photos” - 'światło', „graphoein” - 'rysuję'. Słowo „fotografia” można więc przethumaczyć jako 'rysowanie światłem'. Być może, niebezzasadnie będzie przypomnieć w tym miejscu, że opublikowana w 1844 r. książka W. H. F. T a l b o t a, jednego z twórców nowego medium, nosiła tytuł The Pencil of Nature.

${ }^{61}$ Pisze o tym J. G o n d o w i c z w tekście zatytułowanym Dlaczego Kafka nie fotografowat się nigdy z profilu?, zamieszczonym na znakomitej, niemal wzorcowej, jeśli chodzi o twórczość literacką, stronie internetowej poświęconej dziełom autora Zamku - http://franzkafka.ovh.org/main. htm (data dostępu: 1 III 2012). 
przez niego coraz krótszych tekstów ${ }^{62}$; wreszcie - odtwarzanie (za pomocą zapisanej na fotografii mowy ciała) stanu ducha autora Erotyzmu i traktowanie formy przedstawienia jako wizualnej emanacji konkretnych zdarzeń, jakie miały miejsce w jego biografii intelektualnej:

Na tym zdjęciu prawe oka Bataille'a spowite jest mrokiem; zdaje się wyłupione [...]. Zdjęcie zrobione zostało około roku 1920, kiedy Bataille zerwał z katolicyzmem. Można by powiedzieć, że fotografia dokumentuje utratę przez Bataille'a prawego oka, tradycyjnego symbolu dziennej przenikliwości i pobożności, a zachowanie przezeń tylko oka lewego, symbolu nocy ${ }^{63}$.

\section{Michała Witkowskiego maszyna do fotografowania ${ }^{64}$}

Istnieje fotografia, którą można by potraktować jako idealną wizualizację zarówno tego, o czym pisałem dotąd, jak i tego, co planuję omówić tutaj. Uczynię ją przedmiotem osobnej analizy (choć na pewno nie tak dokładnej, jakiej by wymagała), bo jest oryginalna i da się na jej przykładzie pokazać niemal wszystkie wymienione przez Barthes'a w The Photographic Message procedury konotacyj$\mathrm{ne}^{65}$. Z drugiej jednak strony, ciekawi mnie ona przede wszystkim ze względu na swą wartość egzemplifikacyjną, można ją bowiem potraktować jako charakterystyczną dla zdecydowanie większej grupy przedstawień, pozwalających odtworzyć istniejące w kulturze masowej wyobrażenia na temat pisarza, jego pozycji i znaczenia. Na interesującym mnie tu zdjęciu, którego autorem jest znany fotografik Rafał Milach, za starą, acz pięknie odrestaurowaną maszyną do pisania siedzi

${ }^{62}$ Tego typu stwierdzenie pojawia się w szkicu S t a s i u k a Twarz Samuela Becketta (s. 11-12).

63 J. B il e s, Ecce Monstrum. Georges Bataille and the Sacrifice of Form. New York 2007, s. 213. Cyt. za: T. S w o b o d a, Oko widzialne. „Konteksty” 2010, nr 1, s. 84. Jak przekonuje S w ob o d a (ibidem) w swym tekście poświęconym autorowi Łez Erosa: „każda interpretacja będzie tylko nałożeniem na sfotografowane spojrzenie tego, co [skromny czytelnik] wyczytał już z samego dzieła. Nie znaczy to, że taka monomania jest z założenia pozbawiona wartości. Wręcz przeciwnie, przynieść może obserwacje, dzięki którym to, co do tej pory było tylko intelektualnie poznane, objawi się teraz w sposób bardziej materialny, zmysłowy, namacalny - dosłownie się u n a o c zn i"; „Fotografie kuszą więc i zwodzą, proponują interpretacyjne ścieżki, które okazują się ślepymi uliczkami, lecz z których wracamy bogatsi o to, co swoją naocznością choćby na chwilę wyrwało nas z oków intelektu". Analogiczną konstatację, choć, oczywiście, poczynioną wiele lat wcześniej, można znaleźć u B a r t h e s'a w Świetle obrazu (s. 170, 173): „Guizot jest »podobny«, gdyż zdjęcie zgadza się z jego mitem człowieka surowego, Dumas, szeroki, wylewający się, jest podobny, gdyż znam jego zdolności i płodność; Offenbach - ponieważ wiem, że jego muzyka ma w sobie coś uduchowionego (tak się mówi); Rossini wydaje się fałszywy i cyniczny (wydaje się, więc jest podobny); Marceline Desbordes-Valmore ukazuje na twarzy dobroć, trochę głupawą, swoich wierszy; Kropotkin ma jasne oczy anarchistycznego idealisty itd. Widzę ich wszystkich, mogę spontanicznie powiedzieć, że są "podobni«, ponieważ zgadzają się z moimi oczekiwaniami”.

${ }^{64}$ Fragment ten - w wersji rozszerzonej i zmodyfikowanej - ukazał się w mojej książce Apelacje. Szkice o literaturze i przygodach jej twórców (Katowice 2012).

${ }^{65} \mathrm{R}$. B a r t h e s, The Photographic Message. W: Image - Music - Text. New York 1977. Elementami, które - zdaniem B a r th e s'a - mają budować warstwę konotacyjną zdjęcia, są: charakterystyczne przedmioty, odpowiednie pozy, efekty trikowe, fotogenia (a więc środki gwarantujące fotografii odpowiednią jakość), estetyzm i syntaksa (zdjęcie - co sprawdza się też w tym przypadku - jako element cyklu tworzącego pewną narrację). 
Michał Witkowski ${ }^{66}$. Na pierwszy rzut oka pomysł wizerunku zdaje się opierać na wypróbowanym tylekroć chwycie, gdzie postać jest identyfikowana za pomocą przynależnych jej profesji narzędzi, choć wynikająca z takiego opisu jednowymiarowość byłaby w tym przypadku sporym błędem. Oto już sama nietypowość pozy pisarza - maszyna ustawiona jest przodem do oglądającego, a tyłem do autora Lubiewa, który patrząc wprost w obiektyw równocześnie jednym palcem naciska przycisk klawiatury - prowokuje do rozmaitych interpretacji. Można by np. stwierdzić, że mamy tu do czynienia z alegorią Pisania jako nie do końca uświadomionej gry z mechanizmami języka (Witkowski nie widzi, jaka litera znajduje się na klawiszu, który ma nacisnąć) tudzież Pisarza jako jednostki tyleż twórczej, co pozbawionej kontroli nad znaczeniem, bo ono negocjowane jest w trakcie lektury i dopiero czytelnik/badacz ustala sensy napisanego tekstu. Napisanego? Rzecz w tym, że koncept fotografika nie wyczerpał się jedynie po zaaranżowaniu przestrzeni, a jedno odwrócenie pociągnęło za sobą następne. Oto bowiem z maszyny do pisania - zamiast zadrukowanej tekstem kartki - wyłania się fotografia twarzy Witkowskiego. Jak to rozumieć? Możliwości rysuje się przynajmniej kilka. Po pierwsze (to najbardziej ewidentne rozwiązanie), zdjęcie dałoby się zinterpretować jako formę wizualizacji wspomnianego już wspólnego źródłosłowu, gdzie w miejsce dzieła-tekstu pojawia się dzieło-twarz. Po drugie, jako rodzaj ikonograficznej elipsy, mającej na celu zwrócenie uwagi, iż jeden z wielu powodów, dla których pisarze zaczerniają kartki słowami, stanowi nadzieja, iż w ten sposób utrwalą się w świadomości odbiorców, najwyższą miarą sukcesu literackiego jest zaś w dzisiejszym świecie tyleż poczytność, co rozpoznawalność ${ }^{67}$. Po trzecie, zdjęcie

${ }^{66}$ Analizowane zdjęcie można zobaczyć na stronie internetowej pisarza - www.free.art.pl/ michal.witkowski (data dostępu: 22 X 2010).

${ }^{67}$ Przynajmniej zdaniem niektórych tak jest, acz różne,,akcje promocyjne” podejmowane przez Witkowskiego (np. odnotowany przez internetowe portale plotkarskie zamiar wzięcia ślubu ze znanym stylistą i celebrytą Tomaszem Jacykowem, co zbiegło się dokładnie z momentem publikacji powieści Margot, film reklamowy zatytułowany Witkowski i dziwki, zamieszczony w serwisie YouTube, udział w programie Kuby Wojewódzkiego etc.) wskazują, że popularność rozumiana jako powszechna rozpoznawalność dla autora Lubiewa byłaby czymś upragnionym. Nie bez znaczenia będzie przypomnieć, iż interesujące mnie zdjęcie jest częścią większej sesji, przygotowanej na zamówienie dwutygodnika „Viva!” (2006, nr 4), który - jak wiadomo - literaturą raczej się nie zajmuje, a życiem gwiazd jak najbardziej. Sam Witkowski zresztą wcale tej fascynacji sławą i światem celebrytów nie ukrywa. Przykładowo w rozmowie opublikowanej na łamach „Dużego Formatu” (M. W i t k o w sk i, T. K w a ś n i e w s k i, Witkowski jedzie tirem. „Duży Format” 2009, nr z 21 VIII) pojawia się fragment dotyczący kreacji jednego z bohaterów powieści Margot, celebryty Waldiego Mandarynki:

„-A czy to nie jest tak, że przy okazji pisania sam sobie mogłeś pomarzyć? I jakby zrealizować to, czego nie udało ci się w rzeczywistości zrobić?

- Nigdy nie ukrywałem, że o wiele przyjemniej by mi było śpiewać w Opolu czy w Sopocie, niż pisać książki. Dlatego że jednak co ludzie, to ludzie. Po horyzont. I zawsze większy dreszcz niż jakaś tam sława pisarza. Wychodzisz, wszyscy się drą, ty ich rozpalasz, krzyczysz, oni krzyczą. Wiesz? To jest coś, za co można dopłacać, a co dopiero brać pieniądze. No, ale to już jest sprawa nie do odrobienia".

Cała rozmowa do przeczytania na stronie internetowej: http://wyborcza.pl/duzyformat/ 1,127291,6946944,Witkowski_jedzie_tirem.html (data dostępu: 27 I 2013). W tym kontekście nie od rzeczy będzie zwrócić uwagę, że już wiele lat temu M. M c L uhan (Burdel bez ścian. W: Zrozumieć media. Przedtużenie człowieka. Przeł. N. S z c z u c k a. Warszawa 2004, s. 266-267) zauważył, że fotografia stanowi kluczowy element kultu celebrytów i to właśnie jej zawdzięczają oni swoje narodziny. 
mogłoby być ilustracją zwrotu ku cielesności, tak charakterystycznego dla wszelkich form kultury postmodernistycznej ${ }^{68}$, oraz - apologetycznym albo ironicznym, na pewno zaś inteligentnym - ukłonem w stronę tych postrukturalistycznych myślicieli, którzy z ciałem będą wiązać zarówno doświadczenie lektury, jak i dosyć niespodziewany powrót osoby autora:

Powracający autor nie jest, oczywiście, tym, którego zidentyfikowały instytucje (historia i nauczanie literatury, filozofia, dyskurs Kościoła), nie jest to nawet bohater biografii. Autor, który wychodzi ze swego tekstu i wchodzi w nasze życie, nie posiada spójności; jest prostą wielością „oczarowań”, miejscem kilku zapamiętanych szczegółów, a oprócz tego źródłem żywych olśnień powieściowych [...]; to nie osoba [...], to ciało ${ }^{69}$.

Wreszcie (to zapewne nieostatni potencjalny sposób lektury, niemal oczywisty, acz w interesującym mnie tu kontekście chyba najważniejszy) - wolno tę fotografię odczytać jako przypomnienie skądinąd dość banalnej prawdy, którą duża część artystów przyswoiła sobie już dawno, choć akurat większość ludzi pióra zdaje się ją jednak ignorować. Prawdy opierającej się na przekonaniu, że wizerunek twórcy, analogicznie jak dzieło, może być nie tylko tworem podlegającym interpretacji, ale również znaczącym elementem kreacji podporządkowanej strategii artystycznej (lub raczej ekonomiczno-artystycznej). Strategii w tym przypadku opartej na podwójnej naturze fotografii, praktycznie od momentu narodzin postrzeganej jako wynalazek, którego historię można opowiedzieć jako ciąg dalszy rywalizacji między prawdą a pięknem. Z jednej strony bowiem, ,przedmioty zachowują [tu] swoją formę z matematyczną dokładnością" (by posłużyć się słowami François Araga, fizyka, który w sierpniu 1839 miał przed zgromadzeniem członków Akademii Nauk ogłosić narodziny fotografii) ${ }^{70}$, z drugiej zaś - zostają poddane imperatywowi estetyzacji ${ }^{71}$. Mówiąc inaczej, chodzi o wpisaną w naturę tego medium tendencję do przekształcania fotografowanego obiektu, niezależnie od jego natury, w przedmiot sztuki bądź przynajmniej kontemplacji estetycznej - co część komentatorów witała $\mathrm{z}$ niekłamaną radością (widząc $\mathrm{w}$ tym fakcie jeden $\mathrm{z}$ głównych powodów popularności fotografii), a pozostali-z dużo mniejszym entuzjazmem ${ }^{72}$.

68 Jak ironicznie przekonywał jeden z przeciwników postmoderny: „Postmodernistyczny podmiot tym się różni od swego kartezjańskiego poprzednika, iż ciało jest integralnym elementem jego tożsamości. W istocie wszędzie, czy chodzi o Bachtina, czy »body shop«, o Lyotarda czy o odzież sportową - cielesność jest jednym z najczęściej powracających tematów myśli postmodernistycznej” (T. E a g l e t o n, Iluzje postmodernizmu. Przeł. P. R y m a r c z y k. Warszawa 1998, s. 99).

${ }^{69} \mathrm{~B}$ a r t h e s, Sade, Fourier, Loyola, s. 10. Wieloaspektowy opis różnych sposobów deskrypcji ciała jako jednego z najważniejszych ,odkryć” myśli kojarzonej z postmodernistycznym i postrukturalnym przełomem przynosi szkic A. B u r z y ń s k i e j Ciało w bibliotece (w: Anty-teoria literatury. Kraków 2006).

${ }^{70}$ Cyt. za: S e kula, op. cit., s. 149.

${ }^{71}$ Wątek ten znajduje swoje wieloaspektowe omówienie w rozdziale książki S o n t a g (op. cit.) zatytułowanym Heroizm widzenia.

72 Pierwszą grupę reprezentowałby na pewno Talbot, nazywający swój wynalazek kalotypem (,,kalos” - 'piękny'), a tworzyłaby ją... niezliczona rzesza ludzi pozujących do zdjęć. Oto bowiem, jak ironicznie konstatuje S o n t a g (op. cit., s. 83): ,w połowie lat czterdziestych pewien niemiecki fotograf wymyślił sposób retuszowania negatywu. Dwie wersje tego samego portretu, jakie przedstawił na Exposition Universelle w Paryżu w 1855 roku [...], zdumiały thumy: jeden z nich był retuszowany. Wiadomość o tym, że aparat fotograficzny może kłamać, upiększać - bardzo spopularyzowała zwyczaj chodzenia do fotografa". Drugiej grupie przewodziłby najpewniej W. B e n j a m i n, który w szkicu Twórca jako wytwórca (w: Aniot historii, s. 173) stwierdza: „Staje się ona [tj. foto- 
W przypadku interesującego mnie zdjęcia Witkowskiego wspomniany efekt zyskuje dodatkowe wsparcie w ściśle przestrzeganej regule estetyzacji rzeczywistości rządzącej gatunkiem prasy, w której ta fotografia pierwotnie się ukazała. Kluczowym punktem odniesienia dla fotografika nie jest tu wszak tradycja fotografii portretowej, lecz estetyka przynależna zdjęciom mody i reklamy. W efekcie wtórnym zadaniem okazuje się stworzenie indywidualnego portretu psychologicznego, prymarną bowiem funkcją staje się prezentacja jak najbardziej atrakcyjnego wizerunku. Innymi słowy, prawda przegrywa tu z pięknem, możliwość poprawienia rzeczywistości wydaje się ważniejsza niż wierność wobec niej, od różnicy istotniejsze jest podobieństwo, od różnorodności zaś - homogenizacja, pozwalająca w analogiczny sposób pokazywać modela, gwiazdę serialu, prezenterkę pogody i popularnego pisarza. Taki stan rzeczy, zdaniem Dubravki Ugrešić, nie pozostaje bez wpływu na ludzi parających się piórem. Przynajmniej na tych, którzy upatrują pewnych zależności między wysokością sprzedawanych nakładów a częstotliwością pojawiania się w mediach i widzą związek kariery literackej z funkcjonowaniem w przestrzeni popkultury:

pijanice, artystyczni cyganie, typy w czarnych, robionych na drutach pulowerach z opasłą domową biblioteką w tle, brodaci intelektualiści w tweedowych marynarkach z typowo akademickimi łatami na łokciach i książką w ręce, krótkowzroczni palacze fajek i papierosów wszyscy oni należą do zamierzchłej przeszłości.

$[\ldots]$

W obliczu surowych praw rynkowych pisarki w panice poddają się liftingowi twarzy, thumacząc się zawodem, który tego od nich wymaga. Pisarze coraz częściej prezentują na fotografiach inteligentnie ukształtowane mięśnie i obnażają swoje włochate klatki piersiowe ${ }^{73}$.

Zacytowane słowa można by uznać za żart służący mocniejszemu wyeksponowaniu głoszonej przez autorkę Kultury kłamstwa tezy o końcu literatury, którą zastąpił rynek książki, a wpisaną w nie złośliwość wyjaśnić prawami rządzącymi

grafia] coraz bardziej wymodulowana, coraz bardziej nowoczesna, w rezultacie nie potrafi już utrwalić czynszowych kamienic czy choćby stert śmiecia, aby ich nie opromienić. Nie mówiąc już o tym, że o zaporze wodnej czy fabryce kabli nie jest w stanie powiedzieć nic innego jak to, że świat jest piękny. Swiat jest piękny - to tytuł znanego albumu Renger-Patscha, prezentujący fotografię neorealizmu w jego szczytowym punkcie, jako że nawet obraz nędzy, dzięki modnemu, perfekcyjnemu ujęciu, udało się jej uczynić przedmiotem konsumpcji”. Ten sam fragment, cytowany również przez S ontag (op. cit., s. 103), w przekładzie Magali brzmi znacznie ostrzej: „Udało mu się przekształcić nawet odrażającą nędzę (dzięki potraktowaniu jej w modny, technicznie doskonały sposób) w przedmiot radujący oko".

${ }_{73}$ D. U g r e š i ć, Aura glamouru. W: Czytanie wzbronione. Przeł. D. J. Ć i r 1 i ć. Izabelin 2004, s. 63. Warto w tym miejscu wspomnieć, iż nie tylko pojawianie się w mediach, ale również konsekwentne ich unikanie, paradoksalnie, wzbudza niekiedy podobne zainteresowanie. Przykładem stosowania tego rodzaju strategii mógłby być Julien Gracq czy - przede wszystkim - Thomas Pynchon, który od lat konsekwentnie odmawia jakiejkolwiek publikacji swojego oblicza (ostatnia jego fotografia pochodzi z czasów, gdy uczęszczał na studia). Kiedy w 1997 r. dziennikarze CNN wyśledzili pisarza, ten zgodził się na wywiad tylko pod warunkiem, że telewizja nie pokaże jego twarzy w efekcie istnieją różnorodne hipotezy dotyczące owej postaci, jak chociażby ta, iż ktoś taki naprawdę nie istnieje, a pod nazwiskiem Pynchon kryje się grupa pisarzy i naukowców. Można by (nieco złośliwie) stwierdzić - szczególnie że powieści tego amerykańskiego autora stawiają przed czytelnikami niezwykle wysokie wymagania - iż twórca Tęczy Grawitacji swoją popularność zawdzięcza tyleż literaturze, co kreacji artystycznej. Parafrazując tytuł książki W. G o d zi c a Znani z tego, że sa znani. Celebryci w kulturze tabloidów (Warszawa 2007), można by powiedzieć, iż Pynchon znany jest $\mathrm{z}$ tego, że... nie jest znany. 
poetyką pamfletu. Można by, gdyby... nie znajdowały one pokrycia w rzeczywistości! Aby to udowodnić, sięgam do rozmowy z autorem Lubiewa, z której jednoznacznie wynika, iż bycie popularnym pisarzem (lub aspirowanie do tej roli) wymaga dziś nie tylko świadomości istnienia tradycji literackiej, umiejętności konstruowania fabuły czy posługiwania się językiem, ale i fotogeniczności, odpowiedniej wagi ciała oraz wiedzy z zakresu kreacji wizerunku:

- Znałem cię ze zdjęć i wiesz co? Prawie cię nie rozpoznałem.

- Pewnie dlatego, że przytyłem. Ale to nie jest tłuszcz, tylko - jak mi powiedziała dietetyczka - zatrzymana woda w organizmie. W każdym razie teraz muszę się odchudzić. Mam na to 20 dni, bo za tyle zaczyna się promocja mojej nowej książki.

- Musisz?

- No wiesz, jak to jest, ludzie widzieli mnie ostatnio dwa lata temu, nie mogą teraz powiedzieć: o Boże Święty, co to jest? A z drugiej strony mam świadomość, że to jest takie typowo gwiazdorskie myślenie. Bo zobacz, te wszystkie gwiazdy żyją takim właśnie pulsującym rytmem. Od kompaktu do kompaktu. To znaczy na nowy kompakt trzeba się odchudzić, nażreć hormonów wzrostu, a potem przychodzi dziennikarz i mówi: proszę państwa, przed nami on - piękny, odchudzony, o dziesięć lat młodszy, właśnie wydał nową płytę i w jego życiu wszystko jest otwarte. Nowe możliwości, nowe szanse. A potem, jak to wszystko minie, można się roztyć, zaćpać.

- I ty tak samo?

- Poniekąd. Choć, prawdę mówiąc, najwygodniej byłoby to olać.

- To dlaczego tego nie zrobisz?

- Bo na razie walka nie jest jeszcze definitywnie przegrana. Poza tym mam fioła na punkcie swojego wyglądu. No i jak będę brzydki, to pisma kobiece nie będą się chciały ode mnie dowiedzieć, co sądzę o miłości. I nie zrobią sesji ${ }^{74}$.

W tym miejscu warto wrócić do zdjęcia interpretowanego na początku, a konkretnie do pojawiającej się na nim maszyny do pisania. Oto element, który - jak starałem się pokazać - uruchamia cały ciąg gier semantycznych, równocześnie zaś uaktywnia jeszcze jedno pole sensów, tak charakterystycznych dla wszelkich form palimpsestowych łączonych z estetyką postmodernizmu ${ }^{75}$. Rzecz w tym, iż to samo

${ }^{74}$ Witk ow ski, Kw aśn i e w ski, op. cit. Oczywiście, należy zdawać sobie sprawę, że autor Lubiewa to znakomity prowokator, więc cytowane wyznania trzeba traktować ze sporym dystansem. Omówienie rozmaitych strategii Witkowskiego (tekstowych, ale i medialnych) mających na celu zaprojektowanie odpowiedniego odbioru (dzieła, ale i osoby) przynosi szkic D. Woj d y Borat literatury („Tygodnik Powszechny” 2009, nr 39, s. 18). Sam W it k o w s k i rozpatrując na łamach „Polityki” różne modele obecności pisarza (Pisarz w medialnej sieczce. „Polityka” 2009, nr 42, s. 76) w mediach stwierdził: „Model mój przy okazji ostatniej promocji po raz kolejny wykazał wszystkie swoje wady. Magma wywiadów, których udzielałem masowo, raz po raz dochodzi do mnie w strzępach, poprzekręcane myśli stawia się mi znowu i znowu poprzedzone wstępem: »w poprzednich wywiadach przyznał pan, że... « Masowa produkcja jest to domena chińskiej tandety. W końcu zaczynam tracić rozeznanie, w którym miejscu ja przedrzeźniam obciach i kulturę masową, a odkąd jestem jej częścią. Czy wyznanie o botoksie było jeszcze drwiną z gwiazdorskich wyznań, czy już chęcią wyłudzenia notatek na plotkarskich portalach. W którym miejscu dystans się zmniejsza, gdzie kończy się zabawa? W sumie w mediach sieczkowych można powiedzieć wszystko, ponieważ jest się już poza sensem. Nic nie jest na poważnie, wszystko jest zgrywą. Zaczyna się świat zdewaluowanego słowa. Lecz wówczas ta zgrywa zaczyna obejmować także recepcję dzieła. Skoro autor nie jest już brany na poważnie, to jak jego dzieło ma być odczytywane na serio? A więc? Ucieczka? W model starointeligencki? W model »Tokarczuk«? W coś jeszcze innego?”

75 Jak przekonuje R o u illé (Fizjonomia sztuki-fotografii. W: Fotografia. Między dokumentem a sztukq wspótczesną, s. 441): „O ile odcisk wykorzystywany jest jako podstawowy element dokumentu, odnosząc się do całego systemu fotografii-dokumentu, o tyle w sztuce-fotografii element ten 
- jak wiadomo - nie znaczy zawsze tego samego. W tym przypadku autorowi zdjęcia nie chodziło wyłącznie o uzyskanie kontrastu ufundowanego na zderzeniu zużytego chwytu z nowoczesną formą. Oto bowiem w odróżnieniu od wielu zrobionych w przeszłości zdjęć pisarzy, gdzie pojawia się analogiczny motyw, maszyna na fotografii Milacha nie jest, rzecz jasna, narzędziem, lecz jego imitacją jednym słowem: rodzajem teatralnego rekwizytu! Konstatacja owa wydaje się tu o tyle istotna, iż akcentuje nieco odmienne niż dotychczas wskazywane aspekty fotograficznej ontologii. Na plan pierwszy nie wysuwałaby się tu ani wierność tego medium wobec odtwarzanej rzeczywistości, ani też zdolność do jej estetyzacji, ale to, na co po raz pierwszy zwrócono uwagę przy okazji publikacji słynnego Autoportretu topielca Hippolyte'a Bayarda.

\section{Śpiwór Jacka Podsiadły, kieliszek Marcina Świetlickiego, zloty cielec Tadeusza Różewicza}

Rzecz jasna, Bayard nie był pisarzem ani tym bardziej topielcem. Był jednym $\mathrm{z}$ twórców fotografii - a zarazem jednym z jej wielkich przegranych, jak bowiem wiadomo, splendor związany $\mathrm{z}$ jej wynalezieniem spłynął przede wszystkim na Louisa Daguerre’a. To właśnie on w 1840 roku opublikował swój autoportret, przedstawiając siebie jako topielca. Dzieło owo jest o tyle istotne, iż - jak przekonuje Sławomir Sikora, traktując je, swoją drogą, jako obrazową prefigurację koncepcji ,śmierci autora” Barthes'a - „wydaje się pierwszym (znanym) przykładem, który w tak mocny i ironiczny sposób kwestionuje prawdę obrazu fotograficznego" "76. A zatem niemal od samego początku mimetycznym i dokumentacyjnym walorom nowego medium, tak istotnym dla nauki, został przeciwstawiony twórczy aspekt fotografii, który naturalnie łączył ją ze sztuką. Innymi słowy, okazało się, że mające idealnie odbijać świat lustro, jeśli tylko trafi w odpowiednie ręce, bywa i krzywym zwierciadłem.

odgrywa jedynie drugorzędną rolę, służąc za nośnik dla alegorii. W ten sposób od dokumentu do sztuki współczesnej fotografia przenosi akcent z odcisku na alegorię. Przechodzimy zatem od retorycznej figury śladu (a więc podobnego, identycznego, mechanicznego powtórzenia i od prawdy) do alegorii, która jest podwójna, stanowi różnicę, jest ambiwalentna i fikcyjna".

${ }^{76} \mathrm{~S}$ i k o r a, Kłopoty z fotografia, s. 56. Na odwrocie zdjęcia Bayard zamieścił komentarz demonstrujący, że ironią potrafi posługiwać się równie dobrze w odniesieniu do obrazu, jak i do słowa:

„Ciało, które tu Państwo widzą, należy do pana Bayarda, wynalazcy procesu, który właśnie został Państwu zademonstrowany lub też którego cudowny rezultat będą Państwo mogli dopiero obejrzeć. [...]

Akademia, Król oraz ci, którzy widzieli jego zdjęcia, podziwiali je podobnie jak Państwo to w tej właśnie chwili czynią, choć on sam uważał je ciągle za niedoskonałe. Przyniosło to ich autorowi wiele zaszczytów, ale ani jednego złamanego grosza. Rząd, który wspomógł pana Daguerre'a ponad miarę, stwierdził, że nie może nic zrobić dla pana Bayarda, i ten nieszczęsny człowiek rzucił się do wody w rozpaczy. O, ludzka Fortuno! Przez długi czas artyści, ludzie nauki i prasa interesowali się nim, teraz leży w kostnicy w zapomnieniu, nie rozpoznany przez nikogo.

Panie i Panowie, pomówmy o innych sprawach, aby wasz zmysł powonienia nie został dotknięty, albowiem, jak pewnie to zobaczyliście, twarz i ręce zaczęły się już rozkładać. H. B. 18 października 1840 r." (cyt. jw., s. 20).

Spór Bayarda z Daguerre'em można by pokazać jako rywalizację między sztuką a nauką, bo też jeden znajdował wsparcie w Akademii Sztuk Pięknych, drugi zaś w Akademii Nauk. Na ten temat zob. R o u illé, Fotografia. Między dokumentem a sztuka współczesna, s. 22-23, 227-228. 
Co jednak zaprezentowane konstatacje mają wspólnego z fotografiami pisarzy i maszyną do pisania jako rekwizytem? Wbrew pozorom - całkiem sporo. Rzecz w tym, że lektura wizerunków wchodzi w obręb dyskursu tożsamościowego. Dyskursu, którego użytkownicy równie chętnie sięgają po metafory związane z teatrem i równie często operują dychotomiami przy opisie człowieka, przeciwstawiając wnętrze - zewnętrzu, istotę - pozorowi, autentyzmowi - sztuczność, a twarzy maskę. Tego typu opozycje mają zazwyczaj charakter etyczny, co jednak nie znaczy, że do ich opisu nie można użyć kategorii z zakresu estetyki. Szczególnie iż nie chodzi tu wszak o konieczność podporządkowania się jakimś nadrzędnym regułom i normom (czego efektem byłby podwójny system wartości i zachowań), ale o swobodę w wyborze zróżnicowanych ról społecznych i o umiejętność kreacji wizerunku, traktowanego jako wyraz niezależności artystycznej ${ }^{77}$. Metamorfoza pisarza w aktora, którego sceną jest nie tylko kartka, lecz także wszelkie miejsca kontaktu z czytelnikiem (a więc m.in. ikonosfera), pozwala za pomocą ,twarzy, rąk, ust, oczu, a nawet garnituru, spodni, koszuli i muszki” zamieniać „trociny na złoto” (jak ostrzegał Różewicz) ${ }^{78}$, ale również, miejmy nadzieję, uwydatniać wartościowe zjawiska, które w inny sposób mogłyby po prostu nie być odnotowane. Jaką rolę w tym procederze może odgrywać interesujące mnie medium? Okazuje się, iż całkiem istotną. Oto bowiem - oddaję w tym miejscu głos Sławomirowi Magali:

fotografia stała się jednym z najważniejszych elementów teatralizacji życia społecznego. Jeśli przyjąć, że istotą teatru jest kontakt aktora $\mathrm{z}$ widzem, będący odwołaniem się za pomocą gestu do najistotniejszych doświadczeń zbiorowości, to właśnie fotografia zamienia życie społeczne na teatr powszechny, w którym aktorzy społeczni najróżniejszego rodzaju biorą udział w spektaklu, w którym na oc zni e uczestnic zy wiele milionów ludzi ${ }^{79}$.

W kontekście zacytowanych słów fotografia nie jest już/tylko świadectwem w służbie prawdy, dokumentem obciążonym funkcją identyfikującą, substytutem nieobecnego (etc., etc.), lecz przede wszystkim medium przekształcającym rzeczywistość w obraz, a tym samym grą, kreacją, zabawą. Rozpoznanie Magali - oparte na estetyczno-inscenizacyjnych walorach fotografii, na poszerzeniu pola wi-

${ }^{77}$ Gdyby ten tekst dotyczył wizerunków nie pisarzy, ale np. muzyków, to niniejszy akapit wymagałby kilku zdecydowanych obostrzeń - istnieją wszak zespoły w pełni kontrolowane i podporządkowane wytwórniom muzycznym, które decydują zarówno o składzie grupy, jak i o jej repertuarze, gatunku, tekstach piosenek, wywiadach etc., etc. Są to jednak zazwyczaj przedsięwzięcia bardziej biznesowe niż artystyczne. Choć rynek książkowy w wielu kwestiach upodobnił się do rynku muzycznego i posługuje się częstokroć analogicznymi strategiami marketingowymi, to trudno sobie wyobrazić wydawnictwo, które w podobny sposób traktowałoby pisarza. Z drugiej strony - choć jest to uwaga czyniona w trybie mocno dygresyjnym - nie ma chyba większych zmian, jeśli chodzi o ikonografię, niż te, które w ciągu ostatnich kilkunastu lat zaszły w odniesieniu do prezentacji muzyków trudniących się wykonywaniem muzyki klasycznej. Muzyka poważna, być może ze względu właśnie na to określenie, przez całe lata wymagała takiegoż właśnie wizerunku. Dziś jednak jej gwiazdy częstokroć pokazuje się w odwołaniu do tych samych fetyszy (seksu, zewnętrznej atrakcyjności, nietypowej pozy), co gwiazdy rocka czy muzyki pop - czego najlepszym przykładem są płyty Anny Netrebko czy Anne-Sofie Mutter.

${ }^{78}$ R ó ż e w i c z, op. cit., s. 239.

79 S. M a g a la, Fotografia jako element teatralizacji życia spolecznego. „Fotografia” 1978, $\mathrm{nr} 4$, s. 6. W dalszej części swego wywodu autor przekonuje, iż efektem wspomnianego wcześniej procesu jest ,wymazywanie” rzeczywistości na korzyść tego, co zostaje wykreowane w ikonosferze (to - swoją drogą - brzmi znajomo dla czytelników pism J. B a u d rilli a r d a). 
dzialności, na uprzywilejowanej pozycji zmysłu wzroku w procesie poznania, ale i na pasywności oglądającego, który tym samym przypomina teatralnego widza - wydaje się nie tylko interesujące, lecz (zwłaszcza w odniesieniu do fotografii portretowej) szczególnie ważne. Rzecz bowiem w tym, iż w istotę każdego portretu wpisany jest pewien porządek inscenizacji, zamieniający fotografowanego w aktora, z fotografa zaś czyniący reżysera - co najlepiej uświadamia sam język fotografików, w którym takie leksemy, jak ,poza” czy „pozowanie” pojawiają się nadzwyczaj często ${ }^{80}$. Oczywiście, większość zdjęć próbuje ten inscenizacyjny charakter skrzętnie ukrywać, opierając się na przeświadczeniu, iż jeśli stawką ma tu być prawda (,prawda") o czyjejś osobowości, to nie należy jej budować na kłamstwie („kłamstwie”) obrazu. W rzeczywistości sztucznie kreowana naturalność i jawnie manifestowana teatralność mogą równie dobrze wydobywać to, co stanowić ma o osobowości fotografowanego - o czym najlepiej świadczą zdjęcia Witkacego ${ }^{81}$. Sugerowana $\mathrm{w}$ ten sposób równorzędność tak odmiennych przecież środków ekspresji w istocie jest jednak pozorna. W końcu w teatrze życia codziennego (by posłużyć się tytułem klasycznej pozycji Ervinga Goffmana) odgrywa się wiele spektakli, ale nie wszystkie świadomie i nie wszystkie godne są zapamiętania, podobnie zresztą jak nie każdy repertuar gestów czy zachowań warto od razu uwieczniać. Jaki więc typ zdjęć portretowych wydaje się w tym kontekście najważniejszy? Ujmując rzecz najogólniej: taki, dla którego negatywnym punktem odniesienia są - to pierwsza grupa - zdjęcia amatorskie, $\mathrm{z}$ dominującą warstwą denotacyjną, częstokroć będące pokłosiem jakichś wakacyjnych wyjazdów; mówiąc krótko: zdjęcia prywatne, które dzięki publikacji takimi być przestały (głównym kryterium wyboru wydaje się tu wartość sentymentalna zdjęcia, demaskująca częstokroć, niestety, ikonograficzną ignorancję ${ }^{82}$ ). Drugą grupę - zdecydowanie

${ }^{80} \mathrm{~W}$ pewnym sensie tylko przyzwyczajenie odbiorcze każe nam widzieć np. w portrecie zamyślonego pisarza autentyczny frasunek, a nie pisarza udającego ten stan. O teatralizacji portretu i - szerzej - samej fotografii pisze S o u la ge s (op. cit., s. 81-82), proponując zastąpić słynny Barthes'owski noemat „tym, co zostało odegrane”: „Oglądający zdjęcie sądzi, że jest ono dowodem rzeczywistości, podczas gdy stanowi ono wyłącznie oznakę gry. Każde zdjęcie nas okłamuje. To zostało odegrane, gdyż wydarzyło się i ma miejsce gdzie indziej, niż sądzimy. Tak jak w teatrze, w fotografii nie ma odniesienia ani tam, gdzie się myśli, ani tam, gdzie się jest, ani tam, gdzie się sądzi. Odsyła ona, być może, jedynie do siebie samej. Byłby to zresztą jedyny warunek uzyskania przez nią autonomii”. Oczywiście, i autor $S / Z$ zwracał uwagę na ten aspekt fotograficznego portretu - zob. B a r th e s, Światto obrazu, s. 19-24. Zupełnie osobną kwestią - której istnienie jedynie sygnalizuję, nie mając zamiaru tego zagadnienia rozwijać - jest liczba wątpliwości związanych z przeciwstawieniem tego, co (rzekomo) autentyczne i prawdziwe, temu, co sztuczne i odgrywane. Łacińskie słowo „persona”, oznaczające zarówno osobę, jak i maskę, zdaje się dobrze wprowadzać w istotę problemu. Aby pogłębić jego analizę, trzeba by wszakże sięgnąć do ustaleń badaczy zajmujących się, z jednej strony, psychoanalizą, z drugiej zaś - np. autofikcją.

${ }^{81}$ Autor Nienasycenia jest, niewątpliwie, wielkim nieobecnym tej części niniejszego tekstu. Nie powinno to wszakże być postrzegane jako zaniedbanie, lecz jako świadomy wybór, wynikający $\mathrm{z}$ jednej strony z odmienności gatunkowej tych zdjęć (autoportrety), z drugiej zaś - z faktu, iż fotografie Witkacego doczekały się wielu bardzo ciekawych analiz. Zob. np. szkice zawarte w dwóch albumach: E. Fr a n c z a k, S. O s o ł o w i c z, Przeciw nicości. Fotografie Stanisława Ignacego Witkiewicza. Kraków 1986. - Witkacy. Psycholizm. Red. A. M. Potocka. Kraków 2009 (album ten zawiera szkice m.in. M. P. M ark ow skiego, B. Habrat, A. Żaki ew ic z).

82 Oczywiście, część zdjęć prywatnych w sferze publicznej zaczyna mieć nieco inną wymowę niż w rodzinnym albumie - czego świetnym przykładem analizowana wcześniej fotografia Lipskiej czy zdjęcie Szymutki w krótkich spodenkach widniejące na okładce jego książki Zrozumieć Parnic- 
najliczniejszą, co w znacznym stopniu wiąże się z celową polityką wydawnictw ${ }^{83}$ - tworzą zdjęcia profesjonalne: nienaganne technicznie, zrobione przez zawodowych fotografików, acz równocześnie w pewien sposób „przezroczyste” i pozbawione rysu indywidualnego ${ }^{84}$. Wreszcie trzecią i ostatnią zarazem grupę - zdecydowanie najważniejszą, bo tylko ten typ przedstawień gwarantuje identyfikację $\mathrm{z}$ odpowiednią profesją - stanowiłyby zdjęcia opierające się na powielanym od dawna wzorcu, gdzie za pomocą stosownej pozy (miny), scenerii i odpowiednio dobranych atrybutów buduje się wizualną tożsamość pisarza. Wiarygodność takich obrazów ufundowana jest na zakorzenionej w przyzwyczajeniach odbiorczych (opieram się tu na ustaleniach Goffmana) ,zgodności między dekoracją, powierzchownością i sposobem bycia"85. Zharmonizowanie tych elementów tworzy typ idealny (matrycę), którego funkcję stanowi powtórzenie. To, co gwarantuje wiarygodność, nie gwarantuje wszakże zainteresowania, gdyż dopiero ,zaskakująca niespójność między dekoracją, powierzchownością i sposobem bycia dodaje wielu osobom pikanterii i uroku, a jednocześnie jest atrakcyjnym materiałem prasowym" ${ }^{86}$. Innymi słowy, tylko pisarz, który swą fotografią naruszy istniejącą doksę przedstawiania, ma szansę tak naprawdę zwrócić na siebie uwagę. Jak? Mówiąc najogólniej - decydując się na publikację fotografii generującej jak najszerszą warstwę konotacyjną, opierającą się na jakimś przemyślanym koncepcie, wreszcie próbującą zasugerować symboliczny związek między obrazem a słowem. Mówiąc szczegółowo - można postąpić np. tak, jak Antoni Libera, który na okładce książki Madame umieścił swe zdjęcie z podpisem „Autor w wieku bohatera powieści. Zdjęcie maturalne" ${ }^{87}$, podważając tym samym nieco fikcjonalny charakter tej historii. Można również, jak Witkowski, trzymając w jednej ręce zapalonego papierosa, a w drugiej szklaneczkę z alkoholem (fotografia na okładce Margot),

kiego. Zmiana kontekstu pociąga za sobą bowiem zmianę znaczenia. Niestety, proces ów nie jest obligatoryjny i tego typu fotografie często wydają się raczej przejawem infantylizmu i braku refleksji nad funkcją publikacji własnego wizerunku. Przykładem takiego podejścia mogłoby być np. zdjęcie M. Woźniaka zamieszczone na okładce jego tomiku Wszystko jest cudze - nie dość, że fotografia ta ma kiepską jakość (mały rozmiar, a poeta zbyt oddalony od fotografującego, aby zdjęcie mogło odgrywać rolę dobrego portretu), to jeszcze reprezentuje typ zdjęć, które większość ludzi przywozi z wakacji (pochodzi najprawdopodobniej z wyjazdu do Amsterdamu).

${ }^{83}$ O roli i funkcji autorskich zdjęć z perspektywy wydawnictw wypowiada się, bez szczególnych złudzeń, R ó ż y c k a (op. cit., s. 229): „Pisarz, który rozumie, jak bardzo fotografie mogą się przyczynić do zainteresowania jego twórczością, a przez to i do zawodowego i osobistego sukcesu, musi sprostać wymaganiom dzisiejszej publiczności literackiej, pokładającej duże zaufanie do obrazów. Jeśli pisarz nie rozumie, pomyśli o tym jego wydawca. Skomercjalizowana kultura narzuca swoje warunki, sprawia, że nie tylko książki stają się towarem, który trzeba reklamować; także i wizerunki ich autorów stają się przedmiotem handlu".

${ }^{84}$ Przynajmniej dla przeciętnego odbiorcy, bo - oczywiście - część tego typu zdjęć wpisuje się w różnego rodzaju tradycje szkół portretowych; ich identyfikacja jest wszakże możliwa dopiero przy sporych kompetencjach w tym zakresie.

${ }_{85}$ E. G off $\mathrm{m}$ a n, Człowiek $w$ teatrze życia codziennego. Przeł. H. D a tn e r-Ś p i e w a k, P. Ś pi e wak. Oprac., wstęp J. S za cki. Warszawa 2000, s. 55. Oczywiście, w odniesieniu do fotografii trudno mówić o sposobie bycia sensu stricto, acz z drugiej strony dobre zdjęcie może w tej kwestii wiele sugerować.

${ }^{86}$ Ibidem.

${ }_{87}$ Ten przykład analizuje A. Łe b k ow ska w swej książce dotyczącej empatii (Fotografia jako empatyczna mediacja. W: Empatia. O literackich narracjach przełomu XX i XXI wieku. Kraków 2008). 
zasugerować, że pisanie nie jest wcale pracą, lecz zabawą, egzystencja pisarza zaś niewiele się różni od rozrywkowego życia prezentowanych postaci. Ze względu na fakt, iż - rzecz jasna - nie wszyscy w to uwierzą, można też odwoływać się do zajęć bądź profesji, które współczesna kultura uznaje za atrakcyjne, a przynajmniej za atrakcyjniejsze niż paranie się piórem. Uczynił tak np. Świetlicki - publikując na okładce tomu Trzecia połowa swe zdjęcie z kieliszkiem, symbolicznie nawiązał do mitu le poète maudit, a umieszczając swe zdjęcie z koncertu na okładce 37 wierszy o wódce i papierosach, odsyłał do etosu muzyka. Można także - co wydaje się szczególnie przewrotne, gdy jest się, jak Różewicz, klasykiem - za pomocą odpowiednich fotografii podważać ,,pomnikowy” status pisarza w kulturze (okładki tomów Wyjście i Kup kota w worku), a zarazem wzmacniać projektowany typ odbioru. Można wreszcie - to casus Jacka Podsiadły (tom Dobra ziemia dla murarzy) zdjęciem sugerować określony styl ekspresji (prywatna fotografia odpowiada tu takim terminom krytycznym, jak ,prywatność”, ,autobiografizm”, „,bezpośredniość") czy główne motywy swej twórczości (ten wizerunek poety pochodzi niechybnie z jakiejś wyprawy, więc łatwo go odnieść zarówno do motywu drogi, jak i do tak istotnej dla tej poezji opozycji natury i kultury), konstruując jednocześnie pewien ikoniczny przekaz na temat relacji między podmiotem a autorem. Można... - przede wszystkim można mnożyć kolejne przykłady (i analizować je w zdecydowanie bardziej rozbudowanej formie, na jaką niewątpliwie zasługują), pokazując, iż fotografia na okładce książki już dawno przestała pełnić funkcję li tylko narcystyczno-identyfikacyjną, lecz jest swoistym teatrem jednego aktora, rodzajem pisarskiego performance' $\mathrm{u}$, sceną gier intersemiotycznych.

Co jest ich stawką? Czy istnieje element, który łączyłby ten rodzaj fotografii? Czy z tych różnych strategii ikonograficznych da się wyprowadzić jakąś ogólną regułę? Gdybym miał zaryzykować pozytywną odpowiedź na te pytania, powiedziałbym, że koncepty pisarskie rozmijają się tu z konceptami teoretyków, gdyż droga tych pierwszych wiedzie od tekstu do dzieła, czego najlepiej dowodzi to, iż niespójność wobec wzorca zostaje tu zastąpiona zgodnością względem danego utworu. Mówiąc inaczej, niechęć wobec doksy, czyniącej z pisarza alegorię literatury jako takiej, odpowiada chęci wykreowania wizerunku będącego alegorią jednostkowego dzieła (ewentualnie konkretnej twórczości) ${ }^{88}$. W tym kontekście można by spojrzeć na fotografię pisarza tak, jak Barthes patrzy na kostium teatralny:

Kostium jest pewną é c r i tu re i jest w nim jej dwuznaczność: écriture jest narzędziem w służbie przedsięwzięcia, które je przekracza; lecz jeśli écriture to coś zbyt lichego lub zbyt bogatego, zbyt pięknego albo też zbyt brzydkiego, do lektury nie dochodzi i écriture w swej funkcji zawodzi ${ }^{89}$.

${ }^{88}$ Podobne wnioski zdaje się wysnuwać U g r e š i ć (op. cit., s. 63): „W tym momencie pisarze coraz bardziej przystosowują własny wizerunek do treści swoich książek, a treść książek - do własnej wyobraźni. Dlatego też S. M., autorka krótkotrwałych amerykańskich bestsellerów, fotografuje się w przezroczystej, białej sukni, stojąc w drzwiach obskurnej kloacznej nory. Fotografia wyjaśnia zwięźle treść książki, jest wizualnym blurbem, ale i czymś więcej. Fotografia podsyca fantazje czytelników i sugeruje, że ona, pisarka we własnej osobie, mogłaby być prawdziwą bohaterką mrocznych erotycznych wyczynów opisanych w powieści”.

${ }^{89}$ R. B a rt h e s, Choroby kostiumu teatralnego. W zb.: Maski, t. 2, s. 94 (przeł. E. S z a r y - Matywiecka). 
Rzecz bowiem w tym - jak podkreśla nieco wcześniej Barthes - iż „celem kostiumu nie jest oczarowanie oka, lecz przekonanie oka" ${ }^{90}$. Przekonanie do czego? Przekonanie o czym? Biorąc pod uwagę, że w oczach wielu czytelników prawda wciąż wydaje się jednym z najistotniejszych kryteriów oceny fikcji (pokazał to kapitalnie spór wokół książki Artura Domosławskiego o Ryszardzie Kapuścińskim) oraz wieszczony w różnych miejscach zwrot biograficzny ${ }^{91}$, odpowiedź na to pytanie nie powinna zaskoczyć. Mówiąc najogólniej - chodzi o przekonanie, iż wbrew temu, co twierdzą niektórzy badacze literatury, granice między światem realnym i przedstawionym nie są wcale takie szczelne. Fikcja fotograficznej prawdy, pozwalająca pisarzowi upodobnić się do swoich bohaterów, a bohaterom przypominać autora, byłaby tu jedną $\mathrm{z}$ wielu możliwości powiązania dzieła $\mathrm{z}$ twórcą i ciała ze słowem.

\section{Pies Tomasza Stępnia}

Rok po napisaniu Wstępu do analizy strukturalnej opowiadań (1966), a rok przed ogłoszeniem Śmierci autora (1968), na łamach „The Times Literary Supplement" opublikował Barthes niewielki szkic, dziś uznawany za jeden z najwcześniejszych tekstów zapowiadających wydarzenia, które wkrótce miały zatrząść światem humanistyki. Tekst nosił tytuł Od nauki do literatury, a jego autor przekonywał czytelników (wtedy nieco skonfundowanych):

Logicznym przedłużeniem strukturalizmu może być tylko zespolenie się z literaturą pojętą już nie jako ,przedmiot” analizy, lecz jako działalność pisania, zniesienie wywodzącego się z logiki rozróżnienia, które utworowi każe być językiem przedmiotowym, nauce zaś metajęzykiem, i co za tym idzie, rezygnacja z iluzorycznego uprzywilejowania, jakie nauka wiąże z posiadaniem języka - niewolnika.

Pozostaje więc strukturaliście przekształcić się w ,pisarza” [... $]^{92}$.

Efektem tego przekształcenia - którego dzieje stanowią klasyczne już dzisiaj ogniwo procesów wchodzących w skład najnowszej historii nauki o literaturze - była późniejsza zmiana naukowego paradygmatu, opartego wówczas przede wszystkim na osiągnięciach językoznawstwa ogólnego i na ambicji uczynienia z literaturoznawstwa nauki ścisłej, nastawionej na poszukiwanie wszechogarniających modeli i reguł. W tym kontekście esej Barthes'a nie tylko ujawniał charakterystyczne dla tamtego okresu rozbicie, ale też zapowiadał kierunek nadchodzących modyfikacji. Oto bowiem rezultatem proklamowanego zbliżenia nauki i literatury - rzecz jasna,

90 Ibidem, s. 88.

${ }^{91} \mathrm{~W}$ tej sprawie zgadzać się zdają literaci, krytycy i badacze literatury. Oto, przykładowo, w jednym z ostatnich wywiadów K. Va r g a (Życie to klęska. Z Krzysztofem Varga rozmawia Marcin Sendecki. „Przekrój” 2010, nr 10, s. 62) przekonuje: „Ośrodki opiniotwórcze przesunęly się gdzieś indziej, poza tym sam pewnie dobrze wiesz, że samo dzieło literackie to o wiele za mało, żeby naród się zainteresował. Nadchodzą czasy biografizmu - autor będzie musiał mieć przede wszystkim ciekawy życiorys i niebanalne przygody, a nie być głównie utalentowanym, pracowitym pisarzem przy biurku”. O tym, że czasy biografizmu nadchodzą również dla historyków literatury, przekonywała z kolei A. Na siłow ska (Zwrot biograficzny. Na stronie: http://www.dwutygodnik.com/artykul/553-biografie-zwrot-biograficzny.html 〈data dostępu: 3 XI 2010〉).

${ }_{92}$ R. B a rth e s, Od nauki do literatury. W: Mit i znak. Eseje. Wybór, wstęp J. B ło ń s ki. Kraków 1970, s. 320 (przeł. J. L a le w i c z). 
celowo w tym miejscu upraszczam czy wręcz nieco wulgaryzuję kreśloną tu pokrótce historię ${ }^{93}$ - było postulowanie ujmowania tej pierwszej jako rodzaju pisarstwa („pisarstwa”), a reprezentujących ją tekstów - jako literackich („literackich”). W efekcie literaturoznawca tym się różnił od twórcy bestsellerów, iż - zważywszy na gatunki, które przyszło mu uprawiać, a więc np. szkic interpretacyjny, esej czy monografia - był po prostu pisarzem niszowym ${ }^{94}$.

Cóż to jednak ma wspólnego z fotografią? Odpowiedź nie powinna zaskoczyć: oto praktycznie od początku wyodrębnienia się literaturoznawstwa jako osobnej dziedziny - zdjęcia badaczy literatury podlegały dokładnie tym samym schematom przedstawiania, co fotografie jej twórców. Jeśli więc zdjęcia pisarzy są wtórne wobec tradycji malarskiego portretu, to zdjęcia ich badaczy okazują się swoistym derywatem derywatu. Innymi słowy, fotograficzną tożsamość literaturoznawcy buduje się za pomocą identycznego kodu wizualnego, w którym kluczową rolę odgrywa miejsce (gabinet, biblioteka) i zgromadzone w nim atrybuty (papiery, książki, niegdyś maszyna do pisania, dziś komputer ${ }^{95}$. Przykłady można by tu oczywiście mnożyć, ale najlepszym - zważywszy na rangę nestora polskiej nauki o literaturze - byłoby chyba zdjęcie Henryka Markiewicza widniejące na okładce jego rozprawy Mój życiorys polonistyczny $z$ historia $w$ tle, gdzie autor siedzi nad rozłożonymi przy biurku notatkami lub nad książką, na drugim zaś planie prezentuje się imponująca biblioteka. Brak krawata i rozpięty guzik przy kołnierzyku białej koszuli sugerują, iż sytuacja ma charakter nieoficjalny, niemal prywatny, acz założona marynarka stanowi znak autorytetu i profesjonalizmu oraz sygnał, iż to, czym aktualnie zajmuje się fotografowany, nie jest formą relaksu, lecz pracą.

Zmiana literaturoznawczego paradygmatu, swoista ,antyteoretyczność” i ,proliterackość”, wreszcie „luzowanie teorii” (by posłużyć się określeniami Anny Burzyńskiej ${ }^{96}$ ), charakterystyczne dla postrukturalistycznego przełomu, wpłynęły

93 Jeśli coś ma mnie usprawiedliwić, to przede wszystkim fakt, iż - po pierwsze - rekonstrukcja zachodzących wówczas przemian zdecydowanie wykracza poza ambicje niniejszego szkicu. Po drugie, została ona już drobiazgowo (i fascynująco przy okazji) odtworzona piórem A. B u r z y ńs k i ej w jej dwóch książkach: w Dekonstrukcji i interpretacji (Kraków 2001) oraz w cytowanej wcześniej Anty-teorii literatury.

94 Wyjątkiem - acz raczej tylko potwierdzającym regułę - byliby tu autorzy podręczników, których książki osiągają nakłady, o jakich większość znanych pisarzy może tylko marzyć.

95 Warto podkreślić, że zdecydowanie bardziej restrykcyjnie opisywanych tu schematów przedstawiania trzyma się fotografia prasowa - o ile w przypadku zdjęć towarzyszących książkom zdarzają się różne odstępstwa, o tyle w fotografiach pojawiających się w gazetach istniejąca doksa nie podlega w zasadzie żadnej negocjacji. Jako egzemplifikacja niech posłużą zdjęcia Michała Głowińskiego, które można znaleźć na internetowych stronach „Dziennika” (chodzi np. o łatwą do znalezienia fotografię autorstwa M. Ł o b a c z e w s k i e g o - zob. m.in. http://wiadomosci.dziennik.pl/ wydarzenia/artykuly/85004,lektury-klade-nacisk-na-poezje.html 〈data dostępu: 28 I 2013〉) oraz „Gazety Wyborczej” (tu fotografem był I. Moyr e - zob. m.in. http://wyborcza.pl/55,115575, 7251991,,,9892332.html 〈data dostępu: 28 I 2013〉). Oczywiście, analogiczny schemat stosowany jest także w odniesieniu nie tylko do badaczy literatury, ale do uczonych reprezentujących nauki humanistyczne w ogóle (kod wizualny nauk ścisłych daje nieco inne możliwości - laboratorium, zapisana tablica, specjalistyczna aparatura, biały fartuch nałożony na marynarkę etc.). Być może choć myśl tę opatrzyłbym sporym znakiem zapytania - w ten sposób wracałoby dawne znaczenie słowa „literatura”, będące po prostu synonimem wszelkiego „piśmiennictwa”.

${ }_{96}$ Wszystkie te określenia pochodzą z tekstów Wstęp. Luzowanie teorii oraz Między nauka i literaturą, znajdujących się w książce B u r z y ń s k i e j Anty-teoria literatury. 
nie tylko na podstawy metodologiczne, formę i język rozpraw naukowych, ale również na wizerunek ich twórców. Dobrym przykładem będzie analiza dwóch fotografii, z których jedna odsyła do klasycznego przedstawienia, determinowanego kodem nauki, druga zaś zdecydowanie bliższa jest modelom prezentacji kogoś, kto zajmuje się raczej działalnością artystyczną niż naukową. W ten sposób scjentystyczna powaga związana z poszukiwaniem prawdy, tak charakterystyczna dla paradygmatu strukturalistycznego, znajduje swój wizualny odpowiednik w poststrukturalnym traktowaniu literaturoznawczych dociekań przede wszystkim jako rodzaju gry (sensów). Choć obie pozycje w równym stopniu dotyczą humoru, to tylko jedną z nich można by powiązać z kategorią przyjemności. Oto fotografia Tomasza Stępnia pochodząca z jego debiutanckiej, wydanej w 1989 roku, książki zatytułowanej Kabaret Juliana Tuwima ${ }^{97}$. Na skrzydełku ciemnoróżowej (dzisiaj pewnie powiedzielibyśmy: campowej) okładki pojawia się fotografia autora. Wbrew kolorystyce zdjęcie jest jednak poważne, poza i wyraz twarzy - oficjalne, jasno sugerujące, iż choć o kabarecie będzie tu mowa, to raczej należy spodziewać się powagi. Równo przycięta broda i gładko zaczesane włosy mogłyby być odpowiednikiem naukowej powściągliwości oraz myślowej dyscypliny. 13 lat później (a więc w roku 2003) w tym samym wydawnictwie ukazała się kolejna książka Stępnia (jeśli tamta była powieścią, to tutaj przygladamy się zbiorowi opowiadań). Tym razem nosiła ona tytuł Zabawa - poetyka - polityk $a^{98}$, a zdjęcie autora pojawiło się na tylnej stronie okładki. Zamiast oficjalnej pozy mamy tam prywatną fotografię: włosy są dłuższe, broda krótsza, lecz lekko posiwiała (czas płynie), elegancką koszulę (jej znakiem w dawniejszym wizerunku był duży, zapewne modny wówczas, kołnierzyk) zastąpiła czarna (kolor znaczący) koszulka. Tym jednak, co najbardziej zwraca uwagę, jest pojawiający się na pierwszym planie ukochany pies autora. Czy w ten metaforyczny sposób Stępień próbuje zasygnalizować, że nasza dziedzina schodzi na psy? To pytanie - na szczęście - już nie do mnie.

\section{Postscriptum, albo czaszka Wojciecha Kuczoka}

Jakie było najbardziej niezwykłe zdjęcie pisarza, które znalazłem w trakcie swych fotograficznych peregrynacji? Zdjęcie - na wszelki wypadek uściślę - w pełni oficjalne, widniejące na okładce książki (bez tego kwantyfikatora trudno byłoby chyba rywalizować z wizerunkami Charlesa Bukowskiego $\left.{ }^{99}\right)$ ? Odpowiedź na to pytanie nie jest na pewno łatwa, bo przecież trzeba by wybierać np. między rewelacyjnym zdjęciem Świetlickiego opublikowanym w Schizmie (widać tam wyłacznie ciemny obrys ciała poety oraz jasną plamkę zapalonego papierosa), intrygują-

${ }_{97}$ T. S t ę p i én, Kabaret Juliana Tuwima. Katowice 1989. Brak informacji na temat tego, kto jest autorem zdjęcia, acz sposób jego wykonania sugeruje, że mamy do czynienia z profesjonalistą.

98 T. S tę p i e ń, Zabawa - poetyka - polityka. Katowice 2002. Nie znajdziemy tu notki o twórcy zdjęcia.

${ }_{99}$ Charlesa Bukowskiego można by określić mianem mistrza fotograficznej obsceny, współgrającej jednak z jego barwnym życiem. Istnieje np. fotografia - jej autorem jest słynny fotografik H. Rit t s - na której twórca Szmiry, patrząc wprost w obiektyw, wkłada sobie palce do ust, jakby miał sprowokować wymioty. Na innym znanym zdjęciu (wykonanym z kolei przez M. M o n t fo rta) Bukowski ze spuszczonymi spodniami siedzi na toalecie, w jednej ręce trzymając butelkę piwa, w drugiej zaś - „Playboya”, otwartego na rozkładówce. 
cą fotografią zamieszczoną na okładce zbioru wierszy Cicho, ciszej Jarosława Marka Rymkiewicza (jest to klasyczny portret, tyle że zamiast pozytywu mamy negatyw) a kuriozalnym wizerunkiem Doroty Szczepańskiej z ostatniej stronicy jej skandalizującej książki Zakazane po legalu (odwrócona tyłem autorka ubrana w krótką sukienkę pokazuje czytelnikowi... pośladki). Gdybym wszakże musiał zdecydować się na jedną wyłącznie fotografię, wskazałbym zdjęcie, które nie tyle znajduje się na okładce, co ją tworzy. Idzie o tom opowiadań Wojciecha Kuczoka zatytułowany Opowieści słychane. Oto późniejszy laureat Nagrody Nike jako materię owej okładki wykorzystał zdjęcie... rentgenowskie, będące efektem prześwietlenia czaszki. Ten nieco makabryczny koncept świetnie koresponduje ze snutymi w wymienionym tomie (niesamowitymi) historiami, a równocześnie od tego momentu wszyscy ci, którzy marzą, aby sprawdzić, co kryje się w głowie pisarza, mają już taką możliwość.

\section{Abstract}

GRZEGORZ OLSZAŃSKI

(University of Silesia, Katowice)

\section{NEGATIVES OF POSITIVES OR ON THE WRITERS' PHOTOGRAPHS}

The article refers to a peculiar type of writer's iconography, namely photographs present on the book covers. The photograph, similar to signature, is a sign of affinity and yet a dissentient voice against those literary critical projects which accentuate breaking the ties between the author and the text. Such antitheoretical dimension of writer's photographs is connected to the numerous meanings and senses credited to them. A writer's photograph is thus not only a document with identification function but also a space of creation and autocreation as well, a medium with the help of which the writer (or his/her publisher) attempts at an oftentimes sophisticated play with its reader. In this context a story about the metamorphoses of the writers' representations is also a story about the place and significance of literature in a given society. 